\title{
ICT4D 2016: New Priorities for ICT4D Policy, Practice and WSIS in a Post-2015 World
}

Link to publication record in Manchester Research Explorer

\section{Citation for published version (APA):}

Heeks, R. (2014). ICT4D 2016: New Priorities for ICT4D Policy, Practice and WSIS in a Post-2015 World. (IDPM Development Informatics Working Papers; No. 59).

http://www.seed.manchester.ac.uk/subjects/idpm/research/publications/wp/di/di-wp59/

\section{Citing this paper}

Please note that where the full-text provided on Manchester Research Explorer is the Author Accepted Manuscript or Proof version this may differ from the final Published version. If citing, it is advised that you check and use the publisher's definitive version.

\section{General rights}

Copyright and moral rights for the publications made accessible in the Research Explorer are retained by the authors and/or other copyright owners and it is a condition of accessing publications that users recognise and abide by the legal requirements associated with these rights.

\section{Takedown policy}

If you believe that this document breaches copyright please refer to the University of Manchester's Takedown Procedures [http://man.ac.uk/04Y6Bo] or contact uml.scholarlycommunications@manchester.ac.uk providing relevant details, so we can investigate your claim.

\section{OPEN ACCESS}




\title{
Development Informatics
}

\section{Working Paper Series}

The Development Informatics working paper series discusses the broad issues surrounding information, knowledge, information systems, and information and communication technologies in the process of socio-economic development

Paper No. 59

ICT4D 2016:

New Priorities for ICT4D

Policy, Practice and WSIS in a

Post-2015 World

\author{
RICHARD HEEKS
}

2014

ISBN: 978-1-905469-87-1

Published Centre for Development Informatics

by: $\quad$ Institute for Development Policy and Management, SEED

University of Manchester, Arthur Lewis Building, Manchester, M13 9PL, UK

Email: $\underline{\text { cdi@manchester.ac.uk Web: http://www.cdi.manchester.ac.uk }}$

View/Download from:

http://www.seed.manchester.ac.uk/subjects/idpm/research/publications/wp/di/

Educators' Guide from:

http://www.seed.manchester.ac.uk/subjects/idpm/research/publications/wp/di/educdi/ 


\section{Table of Contents}

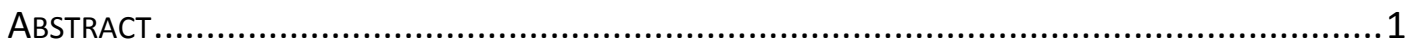

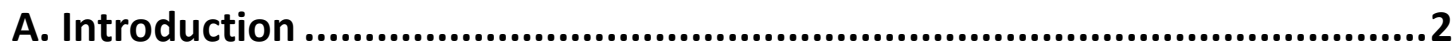

B. Analysis of ICT4D Policy and Practice via WSIS+10 ............................4

C. Future Priorities for ICT4D and WSIS Beyond 2015 ............................9

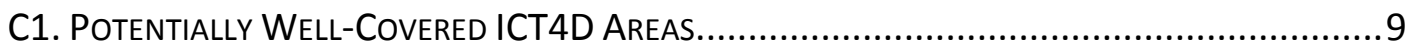

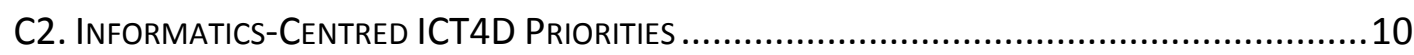

C3. NeW DeVElopMent-ORIENTEd PRIORITIES for ICT4D AND WSIS................................13

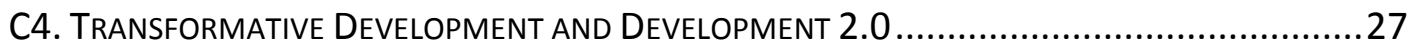

C5. The FutUre Of ICT4D AND WSIS: Structure, ProcesS AND VISION ...........................29

D. Conclusion: ICT4D and WSIS Beyond 2015 ......................................36

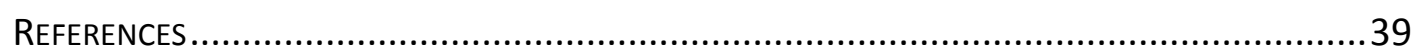

ApPendix A: Most Frequently-ApPearing TeRms In WSIS+10 DocumentATION ...............46

APPENDIX B: COMPOSITION OF KEY DEVELOPMENT ISSUES ..............................................47

APPENDIX C: DiffERENCES BETWEen PoSt-2015 AND ICT4D/WSIS+10 TEXT .......................50

ApPendix D: ICT4D Value ChaIn EMPhases Within WSIS+10 Documentation ................56 


\title{
ICT4D 2016: New Priorities for ICT4D Policy, Practice and WSIS in a Post-2015 World
}

\author{
Richard Heeks \\ Centre for Development Informatics \\ IDPM, University of Manchester, UK \\ Email: richard.heeks@manchester.ac.uk
}

2014

\begin{abstract}
In 2016, the Millennium Development Goals will be replaced by the post-2015 development agenda (PTDA). The foundational content is in place for this new agenda, which will be the single most-important force shaping the future of international development and, hence, the single most-important force shaping the future of information-and-communicationtechnology-for-development (ICT4D). In planning prospective ICT4D priorities, we should therefore pay close attention to the PTDA.

This paper undertakes a comparative analysis of the post-2015 development agenda versus the current content and future direction of ICT4D policy and practice, as exemplified by WSIS+10 documentation. These latter documents bring together nearly 1,000 pages of text that review the current state of ICT4D ten years after the foundational World Summits on the Information Society; and that seek to set out a vision of WSIS and of ICT4D beyond 2015.

From this analysis, the paper identifies a set of post-2015 priorities in international development which have to date been under-emphasised within ICT4D. In all, 16 ICT4D gaps are identified for a world from 2016. These gaps, plus other key topics, are used to create a map of post-2015 ICT4D priorities; a map which will be of significant value to policymakers, strategists and practitioners planning their future ICT4D activities.

Alongside these specific topics, the paper diagnoses a set of cross-cutting issues. It recognises the need for practice to break out of the "ICT4D bubble" and engage more with the development mainstream through a reorientation of ICT4D's scope, language and worldview. And it discusses ICT4D's future structure, process and vision. It identifies the need to retain specialist centres of ICT4D expertise alongside mainstreaming, and the value of multi-stakeholder participation. It highlights the current absence of a compelling narrative and vision for the future of ICT4D: ICT's transformative potential - and the possibilities of "Development 2.0" - might form one such vision. The implications of all these issues are outlined for ICT4D generally and for WSIS specifically beyond 2015.
\end{abstract}




\section{A. Introduction}

If we shape our priorities for information-and-communication-technology-for-development (ICT4D) policy and practice based on the context of broader trends, what trends should we attend to ${ }^{1}$

A simple decomposition of the term shows we could be guided by trends in "ICT" and/or by trends in "4D". Though returning to this briefly later, I will not discuss ICT trends in detail. Some obvious contenders would be: near-ubiquity of mobile, spread of broadband, more big/open/real-time data, use of field sensors/embedded computing, more social media, more crowd-sourcing models, more cloud, more smartphones, and 3D printing. One could also consider related changes such as the move from public and collective to private and individualised models of ICT usage (UNCSTD 2011).

Instead, though, the focus for this paper is the implications of changes in the "4D" context. The Millennium Development Goals (MDGs) have been a key force shaping the international development agenda since the early 2000s. It is argued that the same will be true for the "post-2015 development agenda" (PTDA) which succeeds the MDGs from the end of 2015. This agenda - as argued elsewhere (Heeks 2014a) - is the single best guide we have to future development priorities and goals. Since the aim of ICT4D policy and practice is to use digital technology to achieve development goals, ICT4D beyond 2015 will be significantly shaped by the post-2015 development agenda.

Though not yet fully determined, the main features of that future agenda are already laid down in a number of formative documents. In a previous paper (ibid.), I analysed the static content of the post-2015 agenda from these documents, and also made a dynamic comparison with the MDGs. Table 1 shows the twenty-five key development issues divided into goals, mechanisms and perspectives - which emerged from the comparative analysis. It uses a four-way categorisation to indicate whether the issues are falling down, continuing on, rising somewhat, or rising sharply up the international development agenda. Readers who would like further detail about these issues may refer to that earlier paper.

The aim in this present paper is to identify ways in which ICT4D policy and practice are in synch with these future development priorities; and also to identify out-of-synch elements. These latter may be over- or under-representations within ICT4D which suggest necessary reorientations if ICT4D is to fit with the future of international development. Section $B$ explains how this comparison was undertaken, and why recent materials from the World Summit on the Information Society (WSIS) were chosen to reflect ICT4D policy and practice. Section C examines implications for ICT4D, including 16 policy/practice gaps that need to be filled and a discussion of future ICT4D structures, processes and vision. Section D concludes with an overall map of ICT4D and WSIS priorities in a post-2015 world.

\footnotetext{
${ }^{1}$ Here and elsewhere in this paper, I re-use or modify material from two earlier, related publications that respectively - analyse the post-2015 agenda and its implications for development informatics research: Heeks (2014a) and Heeks (2014b). In essence, this current paper repeats the analysis from Heeks (2014b), substituting policy/practice for research; with both papers using Heeks (2014a) as an analytical foundation.
} 


\begin{tabular}{|c|c|c|c|}
\hline $\begin{array}{l}\text { MDG to PTDA } \\
\text { Change }\end{array}$ & Development Goals & $\begin{array}{l}\text { Development } \\
\text { Mechanisms }\end{array}$ & $\begin{array}{l}\text { Development } \\
\text { Perspectives }\end{array}$ \\
\hline Diminution & $\begin{array}{l}\text { - MDG } 8 \text { with ICTs/Digital } \\
\text { - Manufacturing } \\
\text { - Insecurity }\end{array}$ & $\begin{array}{l}\text { - Traditional Development } \\
\text { Finance } \\
\text { - Development Strategy }\end{array}$ & \\
\hline Continuity & $\begin{array}{l}\text { - Wellbeing } \\
\text { - Infrastructure } \\
\text { - Urban Development } \\
\text { - Institutional } \\
\text { Development } \\
\text { - MDGs 1-6 }\end{array}$ & - Informatics & \\
\hline Some Expansion & $\begin{array}{l}\text { - } \text { Rural/Agricultural } \\
\text { Development } \\
\text { - Services } \\
\text { - Livelihoods } \\
\text { - Growth and Jobs } \\
\text { - Rights and Justice }\end{array}$ & $\begin{array}{l}\text { - New Development } \\
\text { Finance } \\
\text { - Technovation inc. Data } \\
\text { and Mobile }\end{array}$ & $\begin{array}{l}\text { - Complex Adaptive } \\
\text { Systems }\end{array}$ \\
\hline $\begin{array}{l}\text { Significant } \\
\text { Expansion }\end{array}$ & $\begin{array}{l}\text { - Open Development } \\
\text { - Inclusive Development } \\
\text { - Migration } \\
\text { - Environment and } \\
\text { Sustainability }\end{array}$ & $\begin{array}{l}\text { - Development Projects } \\
\text { - New Stakeholders }\end{array}$ & \\
\hline
\end{tabular}

Table 1: Summarising Changes in Development Issues from MDGs to Post-2015 Agenda 


\section{B. Analysis of ICT4D Policy and Practice via WSIS+10}

How does one compare the content and direction of ICT4D with the content and direction of the future development agenda? As noted, the latter is encapsulated in a small set of documents which have been analysed to produce results such as those shown in Table 1. But what can we use to encapsulate the state-of-play with ICT4D?

ICT4D policy and practice are fragmented across many thousands of organisations, tens of thousands of projects, hundreds of thousands of communities, and billions of individuals. The closest we currently have to a node is WSIS: part-structure, part-process that acts as a centripetal force strong enough to draw some ICT4D fragments together.

The two World Summits on the Information Society - the first in Geneva in 2003; the second in Tunis in 2005 - were huge global convocations that set ten ICT4D targets and created eleven action lines (see Box 1$)^{2}$. WSIS+10 is a programme of meetings and activities ${ }^{3}$ which broadly has two components:

- WSIS+10 Review: looking back over the ten years since the WSIS meetings to see what has been achieved; particularly in relation to the action lines.

- WSIS+10 Vision for WSIS Beyond 2015: looking forward to future priorities, strategies and actions that connect digital technologies to socio-economic development.

\section{Box 1: WSIS Targets and Action Lines}

\section{Targets}

Indicative targets to be achieved by 2015 :

a. "to connect villages with ICTs and establish community access points;

b. to connect universities, colleges, secondary schools and primary schools with ICTs;

c. to connect scientific and research centres with ICTs;

d. to connect public libraries, cultural centres, museums, post offices and archives with ICTs;

e. to connect health centres and hospitals with ICTs;

f. to connect all local and central government departments and establish websites and email addresses;

g. to adapt all primary and secondary school curricula to meet the challenges of the Information Society, taking into account national circumstances;

h. to ensure that all of the world's population have access to television and radio services;

\footnotetext{
${ }^{2}$ In addition the Summits set out "A vision of the future Information Society ... Initiatives to improve the measurement of ICTs and ICT impacts ... Mechanisms and institutional formations to address two broad themes in ICT development-Internet governance issues and the financing of ICTs and ICT4D ... Follow-up arrangements for the monitoring and review of WSIS outcomes" (UNCSTD 2011:6). See this source for further details on WSIS.

${ }^{3}$ For further details, see ITU (2014a) and http://www.itu.int/wsis/review/2014.html.
} 
i. to encourage the development of content and to put in place technical conditions in order to facilitate the presence and use of all world languages on the Internet;

j. to ensure that more than half the world's inhabitants have access to ICTs within their reach." (ITU 2003: 15)

\section{Action Lines}

C1. The role of public governance authorities and all stakeholders in the promotion of ICTs for development

C2. Information and communication infrastructure

C3. Access to information and knowledge

C4. Capacity building

C5. Building confidence and security in the use of ICTs

C6. Enabling environment

C7. ICT applications:

- E-government

- E-business

- E-learning

- E-health

- E-employment

- E-environment

- E-agriculture

- E-science

C8. Cultural diversity and identity, linguistic diversity and local content

C9. Media

C10. Ethical dimensions of the information society

C11. International and regional cooperation

Although many real-world fragments are necessarily missing, it is reasonable to argue that WSIS+10's Review and "Beyond 2015" activities are the single best state-of-play guide we have to the present and future of ICT4D policy and practice. The core of this paper is therefore a comparison of text content between two sets of documentation, with the goal of helping ICT4D generally and WSIS specifically get more in synch with the future of development ${ }^{4}$.

The first text set is the four key documents that provide the foundation to date for the post2015 process:

- The initial "Realizing the Future We Want for All" document (UN 2012) and its update "A Renewed Global Partnership for Development" (UN 2013): these are the products in 2012 and 2013 respectively of the UN System Task Team; the core of the post-2015 process.

\footnotetext{
${ }^{4}$ The value of the latter has already been acknowledged within the WSIS+10 process, which recognises the "need for ensuring proper integration of the WSIS and the Post-2015 Development Agenda" (WSIS 2014a:9).
} 
- The report, "A New Global Partnership" (HLP 2013) which was produced in mid-2013 by a High-Level Panel set up by UN General Secretary Ban Ki-moon. This report has been strongly associated with post-2015 discussions.

- The Open Working Group, and High-Level Political Forum, and Expert Committee associated with Rio+20 and the Sustainable Development Goals form a second track of PTDA activities. At the time of writing, they are all in mid-process, so the best guide as yet is the outcome of the Rio+20 conference which is a UN General Assembly resolution of 2012 entitled, "The Future We Want" (UNGA 2012).

The second set of text is ICT4D as reflected by key WSIS papers. Our future can only be based on understanding our present. Thus the post-2015 development agenda documentation is a mix of "where we are now" and "where we want to get to". An equivalent was needed from WSIS and the ICT4D document set was therefore made up of two parts. There were WSIS+10 Review documents:

- The final statement from the February 2013 WSIS+10 Review Event (UNESCO 2013).

- The outcome document from the May 2013 WSIS Forum (ITU 2013).

- The 2014 Executive Summaries of the 10-year WSIS Action Line Facilitator's Reports (http://www.itu.int/wsis/review/reports/).

- The May 2014 "WSIS+10 Statement on the Implementation of the WSIS Outcomes" (WSIS 2014a).

And there were also WSIS Post-2015 Vision documents:

- The May 2013 "WSIS+10 Visioning Challenge: WSIS Beyond 2015" document for the 2013 WSIS Forum (WSIS 2013a).

- The 2013 "Identifying Emerging Trends and a Vision Beyond 2015" document emergent from the 2012 and 2013 WSIS Forums (WSIS 2013b).

- The 2013/2014 zero draft documents of the WSIS+10 Vision for WSIS Beyond 2015 plus summary of submissions received (http://www.itu.int/wsis/review/mpp/pages/phase1outcomes.html).

- The May 2014 "WSIS+10 Vision for WSIS Beyond 2015" (WSIS 2014b).

Each set of documents - the PTDA and the ICT4D/WSIS - was combined into a two overall documents, and then textual analysis was undertaken via comparative word counts, with details provided in Box 2.

\section{Box 2: Comparative Textual Analysis of ICT4D/WSIS vs. PTDA Documentation}

The process began with identification of roughly 200 terms that provided a specific and meaningful sense of direction within the international development agenda. As explained in Heeks (2014a), the term list was developed via selection from the top 500 words counted in the combined post-2015 documentation using Wordle; eliminating all non-discriminatory terms (very simple words like 'and', 'the', 'of'; basic words like 'also', 'must', 'well'; and those which relate to development but do not provide any particular guide to a development agenda such as 'development', 'developing', 'countries', etc). This list was then cross-checked and modified with a similar selection of top 500 terms from documentation relating to the Millennium Development Goals. Further cross-check and modification was then undertaken via 
analysis of the top 150 terms from the WSIS+10 documentation including all those related to the action lines.

The list of the most frequently-appearing of those terms in the WSIS+10 documentation is provided in Appendix $A$.

In order to allow for comparability, the frequency of all terms was normed to a mean count per 10,000 words. The frequency of those terms within the WSIS documents and within the PTDA documents was then compared, calculating the percentage change in frequency per 10,000 words, and the absolute change in frequency per 10,000 words. Since these two measures represent different but important aspects of change, some overall measure was needed: an average of the two. That overall measure was created by using a comparable indicator - standard deviation - and calculating the average variation from zero of each term on the basis of that indicator ${ }^{5}$. Given the large number of terms used, some of them were aggregated into the set of 25 "development issues" shown in Table 1. The basis for that aggregation is shown in Appendix B.

There are challenges in undertaking this comparison. The two sets of documents draw from slightly different disciplinary "languages": the PTDA documents largely from development studies; the WSIS documents somewhat from development studies but also from informatics studies, ranging from computer science and telecommunications engineering through information systems to media and communications studies. A few terms may thus have different prevalence because they have different meanings, e.g. 'security' meaning both human and cybersecurity in the ICT4D/WSIS text, or 'services' covering both the general service sector but also specific broadcasting/broadband/network/telecom/IT/ICT/e- services. Care must also be taken because what one might call the "developmental-richness" of language in the WSIS papers is likely to be lower than for the UN documentation. Therefore one would anticipate a number of issues to appear under-represented.

However, there is a counter-trend. My surmise from 30 years of talking to other ICT4D stakeholders, is that they sometimes feel like foreigners in Developmentland. They can parrot a few terms from the world of development but they cannot speak the language. Those stakeholders need to become not digital natives but development natives; comfortable not just with the words "poverty", "sustainability", "inclusivity" but with their underlying concepts and discourse, and able to engage with the ideas of livelihoods and capabilities, security and wellbeing, justice and vulnerabilities. This state of affairs may mean the extent of use of development terms in ICT4D documents like those from WSIS overstates the reality of engagement in practice, which may in some way partly balance the underrepresentation noted above.

\footnotetext{
${ }^{5}$ Standard deviation is an imperfect indicator for the datasets but since it is not the absolute figure that was important in the calculation, but just some standardised and comparable measure of data dispersion, it serves as an adequate indicator.
} 
Account was taken of these issues by attending not just to bare numbers around aggregated development issues but drilling down to look at individual terms and at the meanings of those terms in context within the WSIS documents. In all, this is an imperfect process but attempts have been made to address the imperfections, and there is some reasonable claim to rigour and validity.

What did the comparison of the ICT4D state-of-play and the post-2015 agenda show? Appendix $C$ shows the foundational data for the exercise at the level of individual terms, and also at the level of aggregated development issues (as a reminder, see Appendix B for the construction of those issues). Figure 1 plots the "ICT4D gap" measure: the extent of difference between the post-2015 discourse and the content of WSIS+10 papers ${ }^{6}$. Issues above the line are more highly represented in the ICT4D documents than in the post-2015 agenda; issues below the line are less highly represented. The larger the indicator the greater the over- or under-representation.

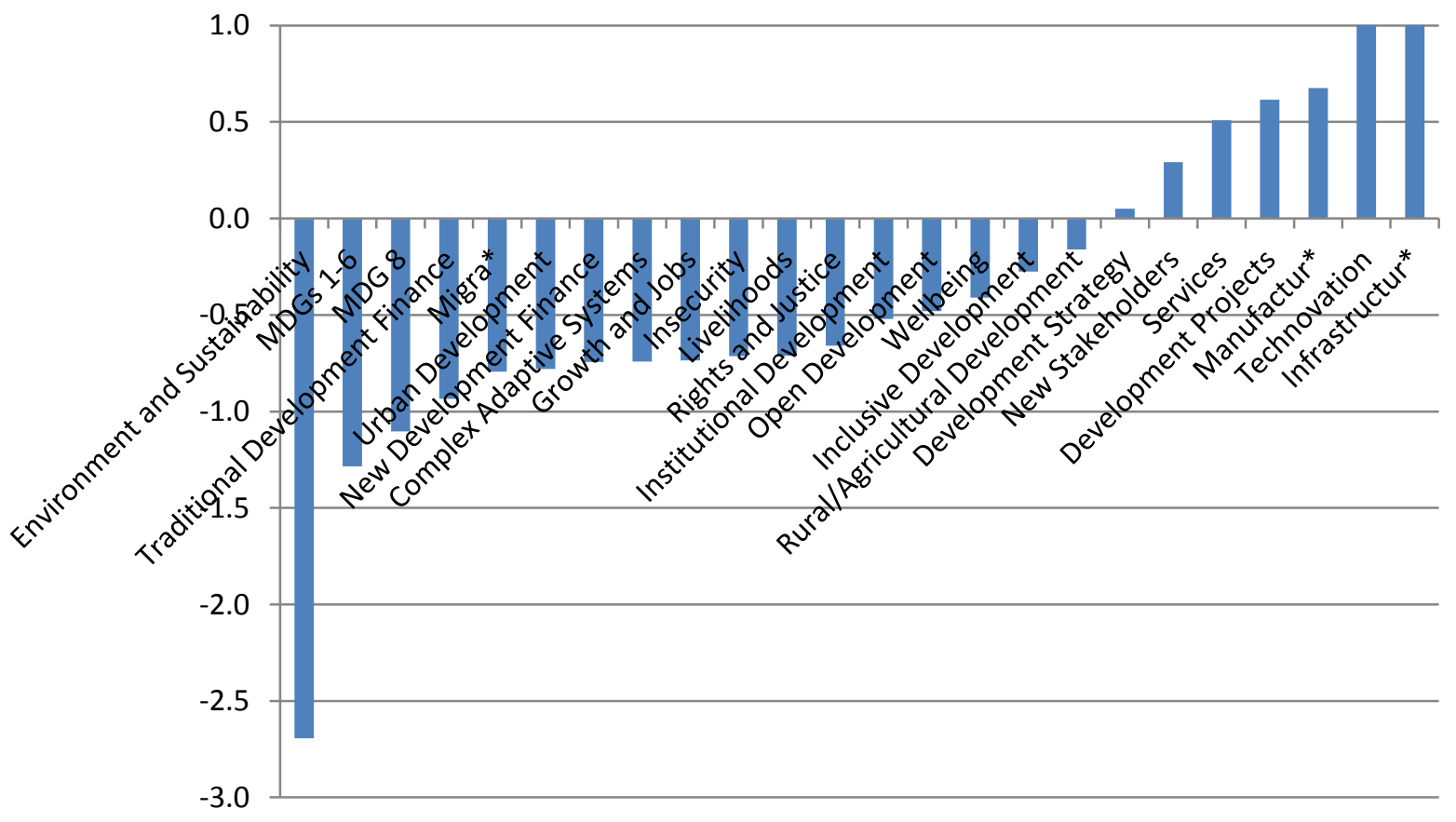

Figure 1: Measure of “ICT4D Gap” Between WSIS+10 and Post-2015 Agenda Text

\footnotetext{
6 "Informatics" has been removed from this chart and its calculations because it is axiomatic that this appears far more often - nearly ten times more frequently - in the ICT4D/WSIS papers than in the PTDA documents.
} 


\section{Future Priorities for ICT4D and WSIS Beyond 2015}

The data presented in Appendix C, including the summary shown in Figure 1, provide the basis for identifying future priorities for ICT4D. That analysis is undertaken below, looking first at both development and informatics topics which show as over-represented in current WSIS documentation. Next - and the main focus of this section - is to look at underrepresented topics plus reading of the WSIS+10 documents and also analysis of the post2015 agenda content and trends (see Section A and Heeks 2014a). Together these are used to produce a list of ICT4D topics that should be given greater priority. Section C ends with discussion of what could be an over-arching ICT4D gap - "Development 2.0" - and some thoughts about future ICT4D structure, process and vision.

\section{C1. Potentially Well-Covered ICT4D Areas}

Items which appear "above the line" in Figure 1 are likely to already be well-represented in ICT4D, as reflected by WSIS, compared to the coming international development agenda. Given the importance and strong role of telecommunications and related infrastructure within ICT4D, it heads the above-the-line items. Technovation is there due to the mentions of 'technology' - to be expected since it is a part of 'information and communication technology' - but also because innovation seems quite central to the current ICT4D worldview.

There are also individual above-the-line items appearing in Appendix C which already have a strong representation in WSIS - ethics (with morality) and culture - led by UNESCO. How strong these strands are within wider ICT4D is an open question, but they do not need further emphasis within WSIS beyond 2015. Learning (and related terms like 'education' and 'knowledge', 'skill' and 'capacit')' is also above-the line. There is a lot of real-world activity around e-learning and developing countries, and at least some of this is captured by the WSIS action sub-line on the topic. It is not in danger of lagging behind the emphasis given in the post-2015 development agenda. The same is true, though to a lesser degree, of e-government and e-agriculture: these have been areas of significant ICT4D - including WSIS - activity, which should be maintained. Science is over-represented in Appendix C and judging from other ICT4D text (Heeks 2014b) it is questionable whether e-science should be given the same standing as, say, e-business, e-agriculture or e-government.

The nature of WSIS - reflecting broader ICT4D practice - is very much in tune with post2015 notions of development practice. While, overall, there is no sense that ICT4D/WSIS should diverge from their current path in terms of development projects, stakeholders or strategy, some pointers do emerge from the detail.

ICT4D/WSIS has a strong emphasis on development projects; particularly around delivery and evaluation. If one wanted to diagnose via the analysis relative weaknesses which require more attention in future, they might be said to lie around:

- Leadership: greater need to recognise and nurture the ICT4D champions who drive forward digital projects and make them succeed (Renken \& Heeks 2013). 
- Monitoring: a shift to ensure more ongoing audit of ICT4D projects as they progress, alongside the current emphasis on post hoc evaluation.

- Impact: a need to ensure that the process of evaluation does not outshine the focus on actual development impact of ICT4D interventions.

Development strategy including ICT4D policy has an appropriate level of coverage within ICT4D/WSIS, though perhaps with their currently being greater discussion of regulation rather than the broader legal frameworks required to support effective use of ICTs in development. WSIS specifically and ICT4D more generally have seen themselves as participative, multi-stakeholder activities which fits well with similar prominence given in the post-2015 agenda. Of course the reality on the ground can be different (Heeks 1999, Haikin \& Duncombe 2013) but the aspiration is clearly there to include the private sector and communities, and particularly to draw in government, citizens, NGOs and academia. ${ }^{7}$

\section{C2. Informatics-Centred ICT4D Priorities}

As noted above, all informatics terms are significantly over-represented in the WSIS papers compared to the PTDA, as one would expect, and many defy meaningful analysis because they appear so rarely in the PTDA documentation. The relative representation of informatics-related terms that appear more than ten times in the PTDA documents, is shown in Figure 2.

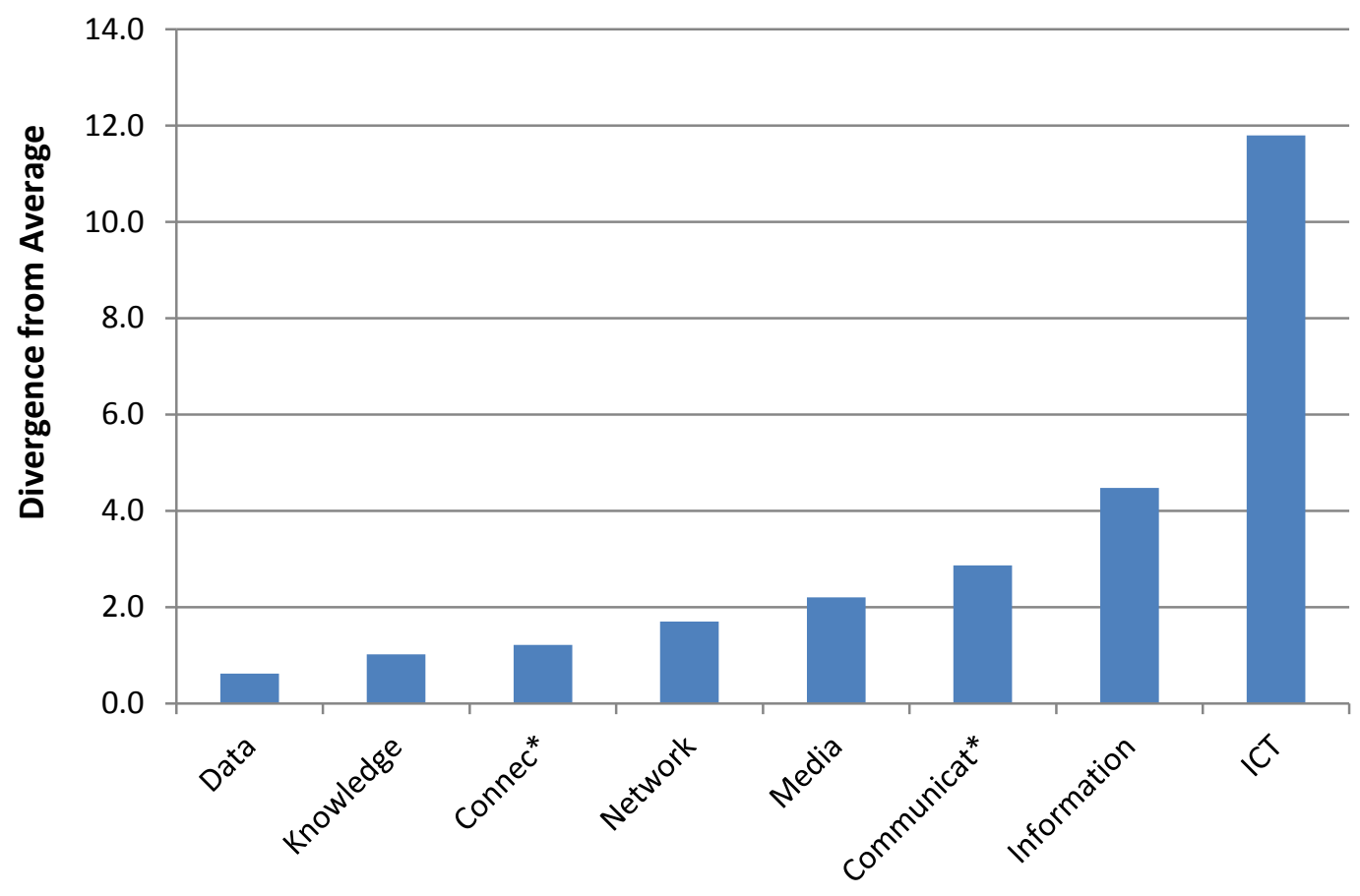

Figure 2: Relative WSIS vs. PTDA Prevalence of Informatics-Centred Terms

\footnotetext{
${ }^{7}$ As for other over-represented terms, as noted in Box 2, 'services' is over-represented due to discussion of technology-specific services. 'Manufacturing' is only mentioned three times in the PTDA document: too few to draw conclusions.
} 
One could try to argue based on relative positioning that more could be made in ICT4D of ideas about networks in development, and about knowledge economies. But the only significant pointer here relates to data. Although somewhat over-represented compared to post-2015 discussion, that can be attributed to discussions about WSIS outcome-related data, which is a separate matter. Overall, the issue of data needs to be given a higher priority within ICT4D.

Within the international development agenda there is already growing interest in this area following the High-Level Panel Report (e.g. ODI 2013; see also identification of the "information revolution" in SDSN 2013), given the HLP (2013) explicitly called for a "data revolution". There are three dominant aspects to a development data revolution:

- Big development data: the emergence of very large datasets relating to phenomena within developing countries. One main source has been mobile phone call records which have been used, for example, to examine intra- and inter-country migration (Molony 2012); but there are many other emerging and potential applications (ESS 2013).

- Open development data: the greater availability of developing country datasets for general use. By far the biggest growth area has been open government data which is particularly linked to improvements in accountability and in service delivery, as discussed further below (Davies et al 2013).

- Real-time development data: the availability of developing country data in real time; that is, simultaneous to the moment of the data-creating event. To date, lagged models have been dominant within developing country data and decision-making, with data becoming available months or years after the events that it describes. The growing diffusion of ICTs within developing countries is reducing this lag significantly to allow real-time or near-real-time use of data for development decisions (Global Pulse 2013).

Despite this potential, 'open data' alongside 'personal data' only register a couple of mentions per 10,000 words in the WSIS documents, while 'big data', 'real-time data' or any sense of a 'data revolution' are hardly mentioned. Other elements of the data revolution geo-locational data, mobile data, user-generated data - are not mentioned at all.

The sense therefore is that any data revolution in development is a party to which the ICT4D community is not yet invited and is making few efforts to gatecrash. One can see that reflected within the UN system where the data revolution flag-bearer - Global Pulse appears to have little connection with established ICT4D actors, and is never once referred to in WSIS+10. If data-for-development develops independently of ICT4D, this will be to the detriment of both: D4D will miss out on valuable knowledge, experience, contacts and mechanisms to scale; ICT4D will be sidelined from a bandwagon that will gather funding and political attention. Instead, ICT4D generally and future WSIS specifically need to first embrace and then start to drive the data revolution. This will required changed priorities but also a changed mindset and language (see Box 3). 


\section{Box 3: From "ICTs" to "Informatics"; From "ICT4D" to "I4D" - Changing the Language and Worldview of ICT4D and WSIS}

Although used in this paper as one of the a very few aggregate terms, 'informatics' only appears 17 times in the WSIS+10 documentation (often in the name of an institution) whereas ICT appears 2,590 times.

This is a problem, as is the terminology of ICT4D, because it can throw too great a spotlight on the technology and on technology-related issues like access and infrastructure. It encourages technologically-deterministic designs that fail when they meet social realities. Now is the time to switch to the language of "informatics", encompassing data, information, knowledge, information systems, and information and communication technologies.

In part this is just good sense to reflect systemic and social realities. In part this is good politics. An informatics label will allow WSIS, the UN Group on the Information Society (UNGIS) and other ICT4D stakeholders to lay claim to the data revolution. Without this, the data revolution will drag attention and resources down its own potentially-isolated path.

If we follow this logic, then the domain should change from ICT4D to I4D: informatics-for-development.

\section{C2a. The Dark Side of ICT4D}

ICT4D has not given sufficient acknowledgement to the dark side of ICT4D. The central perceived problem issue - the cuckoo that tends to push all other problems out of the nest - is the digital divide. But that is a constraint not a disbenefit of ICT; it reflects a worldview that still associates the technology per se only with benefits: "ICT is a wonderful thing and our challenge is to help everyone have effective access".

There is a WSIS action line - C10 on "Ethical Dimensions of the Information Society" - which does encompass the disbenefits; but the focus is relatively narrow, and largely driven by a rights-based approach that emphasises privacy and freedom of expression. And action line C5 on "Building Confidence and Security in the Use of ICTs" directly addresses concerns about cyber-security with a nod towards online protection particularly of children. But these are significantly outweighed in the overall agenda of challenges by the digital divide, and that agenda is itself significantly outweighed by the agenda that ICT is a good thing that brings development benefits.

Even the disbenefits that are acknowledged rate barely a mention in the two core review and vision documents (WSIS 2014a, WSIS 2014b). In the overall documentation analysed more than 900 pages of text - failure is mentioned just twice (only as a risk, not a reality); pornography and viruses are mentioned just once; hacking and work/life balance and cyberwarfare are never mentioned. This reflects a broader sense of marginalisation of the dark 
side - as judged by lack of research analysis - within ICT4D (reviewing the more than 100 papers analysed for Heeks 2014b; see also Heeks 2013a) and within ICT generally (Tarafdar et al 2013).

Two things need to happen. There needs to be greater priority and attention given to identifying, measuring, analysing and addressing ICT4D's disbenefits. And there needs to be an expansion of the disbenefits covered: not just security/privacy/protection but also:

- The costs and failures of ICT4D (e.g. Marais 2011).

- The development of a Cluedo piece-shaped ${ }^{8}$ labour market in which the bulk of jobs are low-paid; mid-level jobs are squeezed out by ICT; and only a very few elite information society workers benefit (e.g. Boehm 2013).

- The loss of work/life balance and growing stress through use of ICTs (e.g. Demerouti et al 2014).

- Short- and long-term negative impacts of ICT use on health, learning and cognitive development especially among children (e.g. Punamaki et al 2007, Sigman 2011)

Of course there are socio-technical, not technical causes to these disbenefits, but they arise via ICT and they will increasingly come to the fore as ICTs penetrate ever-further into development. They will demand increasing resources, and they will need to form an increasing part of future ICT4D policy and practice.

\section{C3. New Development-Oriented Priorities for ICT4D and WSIS}

What of under-represented items? As can be seen from Appendices B and C, the aggregated development issues sometimes bring together elements with very different stories, and therefore Tables $\mathrm{C} 1$ and $\mathrm{C} 2$ are used together in what follows. As noted in Box 2 , these were not simply taken at face value but were read in relative as much as absolute terms, and were also read in context within the WSIS+10 documents. Additional data for the creation of the priorities that follows comes also from both the static analysis of content of the post-2015 agenda (reported in Heeks 2014a) and, especially, a dynamic analysis of trends in the post-2015 agenda (ibid.), a summary of which was presented in Table 1. 
This combined analysis - plus the analysis in earlier parts of Section C - produces the "sixteen for 2016 onwards" largest ICT4D gaps, in descending priority order", shown in Table

2. Three items have already been discussed, and the remainder are analysed next.

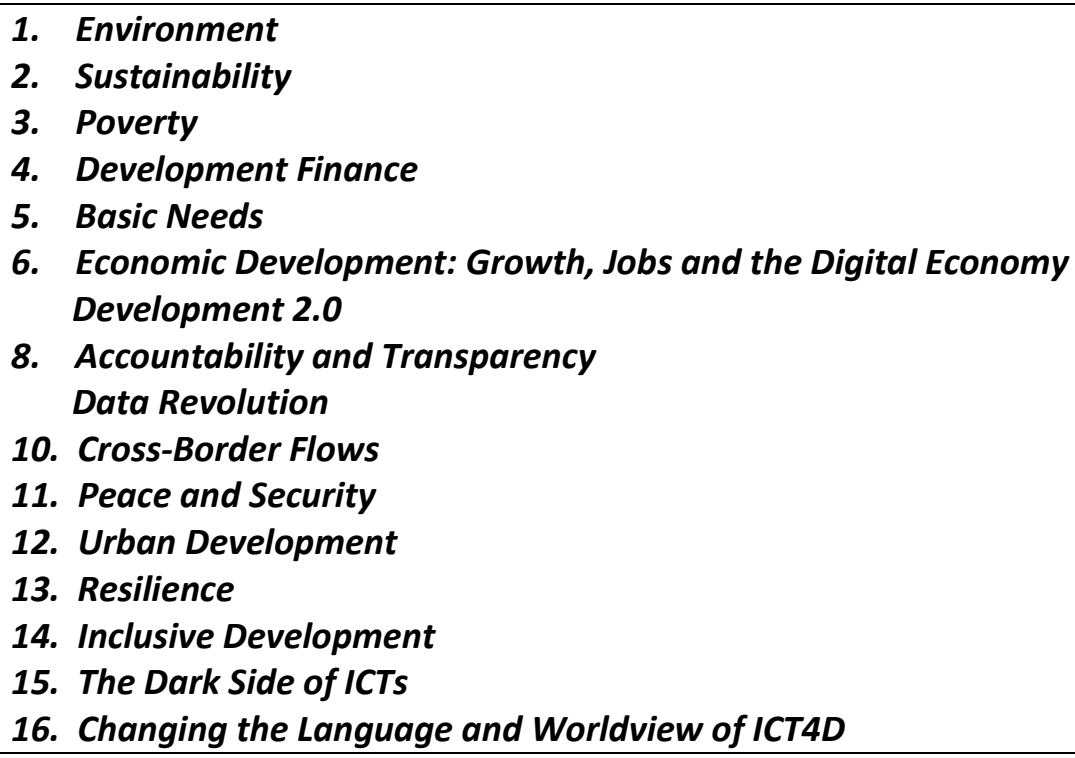

8. Accountability and Transparency Data Revolution

10. Cross-Border Flows

11. Peace and Security

12. Urban Development

13. Resilience

14. Inclusive Development

15. The Dark Side of ICTs

16. Changing the Language and Worldview of ICT4D

Table 2: Top Post-2015 ICT4D Gaps

The argument here is not that no ICT4D activity exists in these areas; but that these represent the greatest differences between the priority accorded to a topic in the post-2015 agenda and the presence of that topic within future-oriented ICT4D discourse as represented by the WSIS+10 documentation. Each one would of course require extensive reading of current materials in both the development and ICT4D spheres in order to accurately locate the future priorities. There is only space here to give a brief discussion, and this should be read in conjunction with discussion of the role of these issues on the development agenda in Heeks (ibid.).

\section{C3a. Environment}

Within the post-2015 agenda, environmental development is the most highly-emphasised of the four development domains (the others being social, economic and political). There is a strand of activity within ICT4D on ICTs and the environment - for example, reflected in the WSIS C7 sub-line on "e-environment". But it is too far down the ICT4D priorities list - it should be at the top - and it is also too narrowly defined. The description of priority within the WSIS post-2015 vision (WSIS 2014b:11) is a good example: "developing Green IT and using ICTs to mitigate climate change". Adding later text, we find the current ICT4D agenda focuses mainly on three areas:

\footnotetext{
${ }^{9}$ Though discussed separately, Development 2.0 is shown where it should appear $-6^{\text {th }}$ equal - based on the textual analysis. The items from Section C2 use a different approach and two are placed at the end of the list for lack of any other guidance. The 'data revolution' item is placed $8^{\text {th }}$ equal alongside accountability and transparency because a key constituent - open data - relates so directly to those issues, as explained in the text.
} 
- Mitigation of climate change through green IT innovations that use less power or fewer resources in their design, construction and distribution.

- Monitoring, mainly of weather and including both long-term tracking and short-term early warning systems.

- Minimisation of e-waste through improved design and recycling.

These are all important aspects of the relation between ICTs and the environment but they largely represent an agenda of the global North and the ICT sector, rather than an agenda of the citizens of the global South. The no.1 environmental issue facing those citizens is the need to adapt to climate change and, hence, the no.1 e-environment priority should be use of ICTs to enable climate change adaptation (Pant \& Heeks 2011). Yet climate change adaptation is not once mentioned in the two core WSIS documents (2014a, 2014b); it rarely appears in the wider documentation; and there has been little or no attempt by developing countries to develop a comprehensive plan for ICTs and climate change adaptation.

Alongside adaptation, mitigation and monitoring, then 'strategy' is the fourth domain of climate change to which ICTs can contribute (Ospina \& Heeks 2012). Again, this has little presence in current ICT4D priorities, and more must be done, particularly in using ICTs to support climate change policy-making and National Adaptation Programmes of Action.

Finally, two domain-specific but environment-related uses of ICT in developing countries are under-prioritised in comparison to the future of development:

- Energy: use of ICTs to improve energy supply and energy security in developing countries, including greater use of renewable sources.

- Water/sanitation: strengthening the links between ICTs and water from modelling and mapping fresh and underground water systems, to reporting mechanisms on water supply points. Similar work is also needed to strengthen the role of ICTs in improving sanitation systems.

\section{C3b. Sustainability}

Sustainability represents by far the strongest theme of the post-2015 development agenda: mentioned around three times more often than the next development theme. It is also by far the most comparatively under-represented term in the analysed ICT4D documentation. Per se, that would suggest ICT4D policy and practice needs to pay far more attention to sustainability, but this need becomes far more pressing when one looks at the detail of how sustainable development is handled in the ICT4D domain. Essentially - as manifest in the WSIS text - "sustainable development" is an empty slogan: continuously invoked but never examined.

Examples of the merely-rhetorical status of sustainable development within ICT4D discourse (WSIS 2014b) include an example of how "E-government can support sustainable development":

- "Foster e-government services while meeting the challenges of privacy and security." And examples of "Exploitation of technological innovations for sustainable development":

- "Create and support thematic information networks such as industry, trade, agriculture, health, education and others. ... Develop digital terrestrial television and mobile 
Internet. ... Acquire new frequency bands to the civilian use. ... Harmonize management of radio spectrum."

There is no sense of any adjustment of focus to specifically engage with the meaning of sustainability. "Sustainable development" and "sustainability" are simply the phrases du jour that are included without real thought.

To be fair, the post-2015 documentation can often seem the same, but there needs to be more thought about what type of sustainable development paradigm should guide ICT4D in future, and what the implications are for policy and practice. The absence of this is one reason why the Sustainable Development Goals draft available at the time of writing (DSD 2014) makes no mention of ICTs.

Even basic definitions of sustainable development would help. The extended version of the much-quoted Brundtland Report definition (WCED 1987:43) could be one starting point:

"Sustainable development is development that meets the needs of the present without compromising the ability of future generations to meet their own needs. It contains within it two key concepts:

- the concept of 'needs', in particular the essential needs of the world's poor, to which overriding priority should be given; and

- the idea of limitations imposed by the state of technology and social organization on the environment's ability to meet present and future needs."

This already sets up a tension between current and future needs, and between needs and limitations, which can be explored. Further explored can be the tension between the three "pillars" of sustainable development (mentioned but never explained in the WSIS+10 core documents) - economic prosperity, social inclusion and environmental sustainability which cannot all be simultaneously maximised and must thus be balanced; see also Figure 3 below (World Bank 2001).

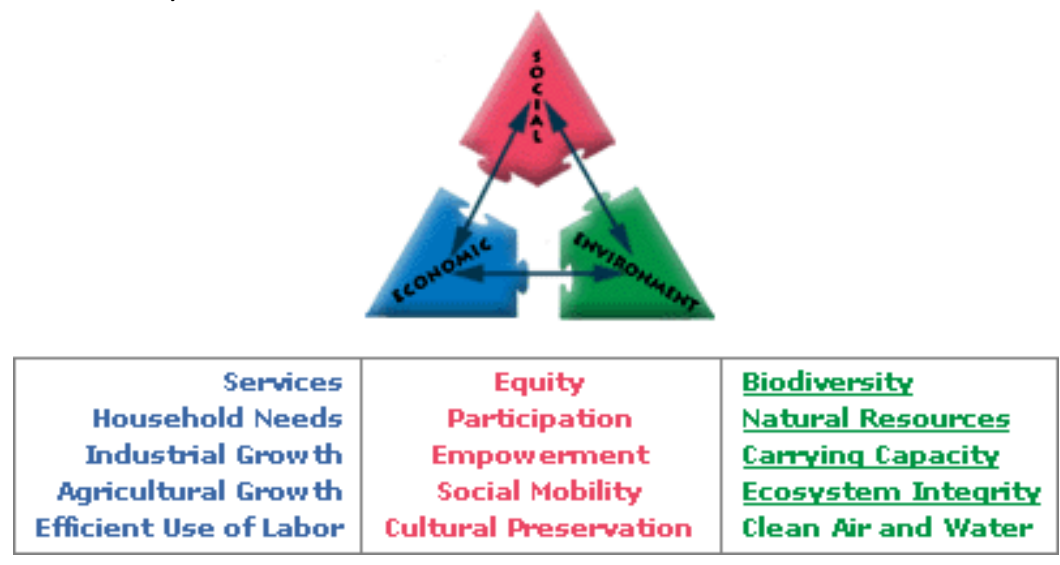

Figure 3: The Components of Sustainable Development

That these component parts are largely confined to a few sub-lines within WSIS is one problem, but there also needs to be recognition of the way in which ICTs can help support the political debate around the tensions identified above. 


\section{C3c. Poverty}

Poverty was central to the MDG agenda and remains central to the post-2015 agenda. Yet, after sustainability, it is the second-most comparatively under-represented term in ICT4D/WSIS, with no action line within WSIS and no specific suggestion on how ICTs will be used to address poverty. This reflects a wider failure of ICT4D thinking to engage with poverty and with the discourse and theories of poverty (Heeks 2014b): see also Box 4. There have been some recent moves to encourage this engagement (e.g. Adera et al 2014, Heeks 2014c) but it must also happen in practice, with greater insertion of ICTs into Poverty Reduction Strategy Papers and their strategic equivalents (with poverty-specific rather than just generic ICT priorities), into poverty policies, and into poverty reduction/eradication programmes and projects.

\section{Box 4: ICTs and the Development Agenda: Everywhere but Nowhere?}

The particular terms 'ICTs' and 'digital' have slipped down the development agenda when we compare the MDGs and post-2015 framework. This is not true of related terms like 'data' or 'mobile', which have grown. As a result, the aggregate term 'informatics' has a stable presence from MDGs to post-2015 agenda. That overall picture can be seen to reflect an averaging of two trends.

First, an inevitable descent from the heights of the early 2000s. The MDGs were written around a peak of global interest in ICTs. That wave rolled on into the 2000s, reaching a crescendo at the 2005 Tunis World Summit on the Information Society, attended by more 19,000 participants. There then followed a loss of momentum with a rhetoric of "mainstreaming" ICTs covering a reality of sidelining ICTs (Heeks 2010a). Like adulterers in the wake of a fling, many in development seemed embarrassed by their earlier gushing enthusiasm for ICTs and - sometimes quite explicitly - wanted to blot their erstwhile paramour from their memories during the latter part of the noughties. But during the 2010s there has been some recovery, with new donor programmes emerging, though by no means reaching the earlier level.

That recovery arises particularly from the second trend, which is the phenomenal growth in ICTs worldwide. Summarised in Figure 4 (ITU 2014b), this shows the world has moved from a promise to a reality of digital infrastructure in development: from 12 mobile phone subscriptions per 100 inhabitants in the world in 2000 to 96 in 2013; from 8 Internet users per 100 inhabitants in 2001 to 40 in 2013; and from 0.6 broadband subscriptions per 100 inhabitants in 2001 to 40 in 2013.

Thus, digital technologies have become ever-more important in the lives of ordinary citizens in developing countries, with a clear trajectory that they will become just as integral to economic, social and political life as they have done in the global North. 


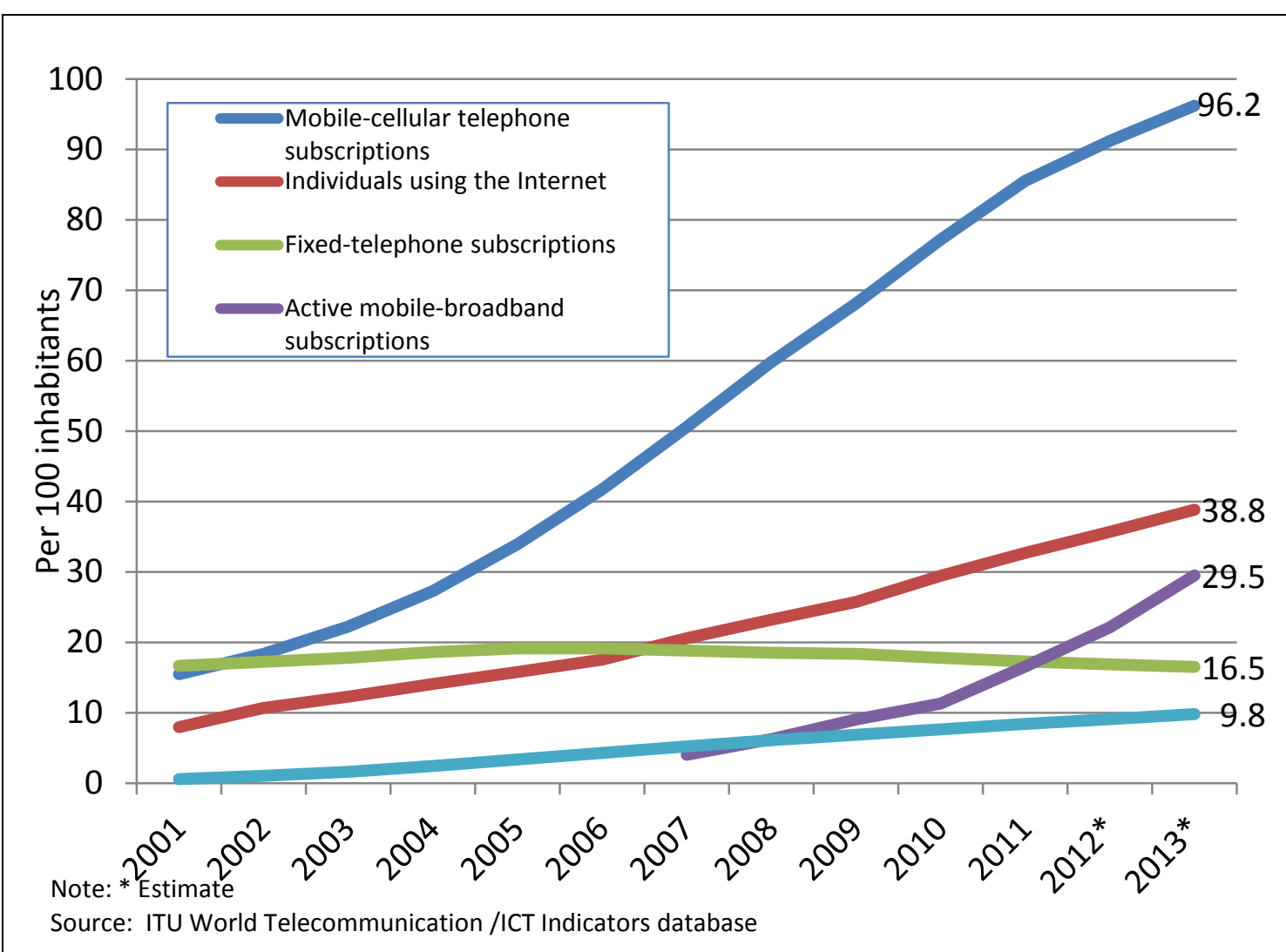

Figure 4: Global ICT Developments 2001-2013

And yet - notwithstanding this growth trend in diffusion and application, plus the growing interest in data - we are still left with the pattern that ICTs showed a strong descent down the international development agenda during the 2000s, with at best a small recovery more recently. Even that recovery is questionable: as noted above, ICTs find no place in the current version of the Sustainable Development Goals. We could thus be witnessing the bizarre concurrence of ICTs touching and shaping evermore aspects of international development at the same time as they disappear from the international development agenda.

One reason for this may be the failures noted in the main text and in Box 2:

- ICT4D's inability so far to effectively and significantly engage with the twin colossi of development goals going forward: poverty eradication and environmental sustainability; which partly relates to

- ICT4D's inability to really speak the language of development: not just saying the words but grasping the underlying meaning and grammar by fully understanding development concepts and discourse; and

- ICT4D's inability to create a compelling role for itself in emerging development paradigms of sustainable development and (see below) inclusive development.

These failures are the core tasks that ICT4D generally - and WSIS specifically should set itself to rectify if it wants ICTs to return to their appropriate place in the development agenda. 


\section{C3d. Development Finance}

Notwithstanding a post-economic crisis dent, overall levels of aid/official development assistance (ODA) show an overall growth trend since the turn of the century. For threequarters of very poorest countries (those with government spending of less than US\$200 per person per year) ODA still represents the single largest financial inflow (DI 2013a, DI 2013b). But growth rates of both remittances and foreign direct investment have been even higher, with these plus discussion of taxation and philanthropy all showing a growing presence in the development agenda if we compare post-2015 to the MDGs.

But all this is poorly-reflected in current ICT4D priorities with every aspect of development finance, whether new or traditional, under-represented in WSIS+10 text compared with the post-2015 development agenda - finance, aid/ODA, debt, banking, donors, tax, philanthropy, investment, remittances and money - some of which are not mentioned at all. There is only a little recognition of mobile money in the WSIS documents, and WSIS is therefore a poor reflection of practice in this case: $\mathrm{m}$-Pesa may be the poster child for these applications but m-money is already an active and important area of ICT4D in very many developing countries (GSMA 2014).

This does not mean WSIS has ignored finance and investment; far from it - there has been a particular focus on financing and investment of various aspects of ICT4D. But this is the first of a number of examples where the agenda remains trapped in an "ICT4D bubble"; looking inwards to the ICT domain instead of connecting outwards to the development domain (a further example of the concerns outlined in Box 3).

What ICT4D needs to do is break out of the bubble, and connect to the development finance agenda by giving a higher prominence to:

- use of ICTs to manage and monitor aid flows and debt;

- use of ICTs in mainstream banking and finance;

- use of ICTs to improve tax systems and also taxation of ICTs (the mobile sector forming a core and growing tax base for many developing countries);

- ICT-enabled investment channels; and

- e-remittances (though covered to some extent already due to remittance being a core use of mobile money transfer).

A WSIS action line on this would not go amiss.

\section{C3e. Basic Needs}

It has been much-criticised over the years but Maslow's (1943) hierarchy of needs is also much-valued, and the bottom levels of the hierarchy (see Figure 5; from Schop (2009)) are a credible representation of basic human needs. They have also shaped the "basic needs" approach to international development, which argues that these basic needs must be the main development priority (Streeten 1984). 


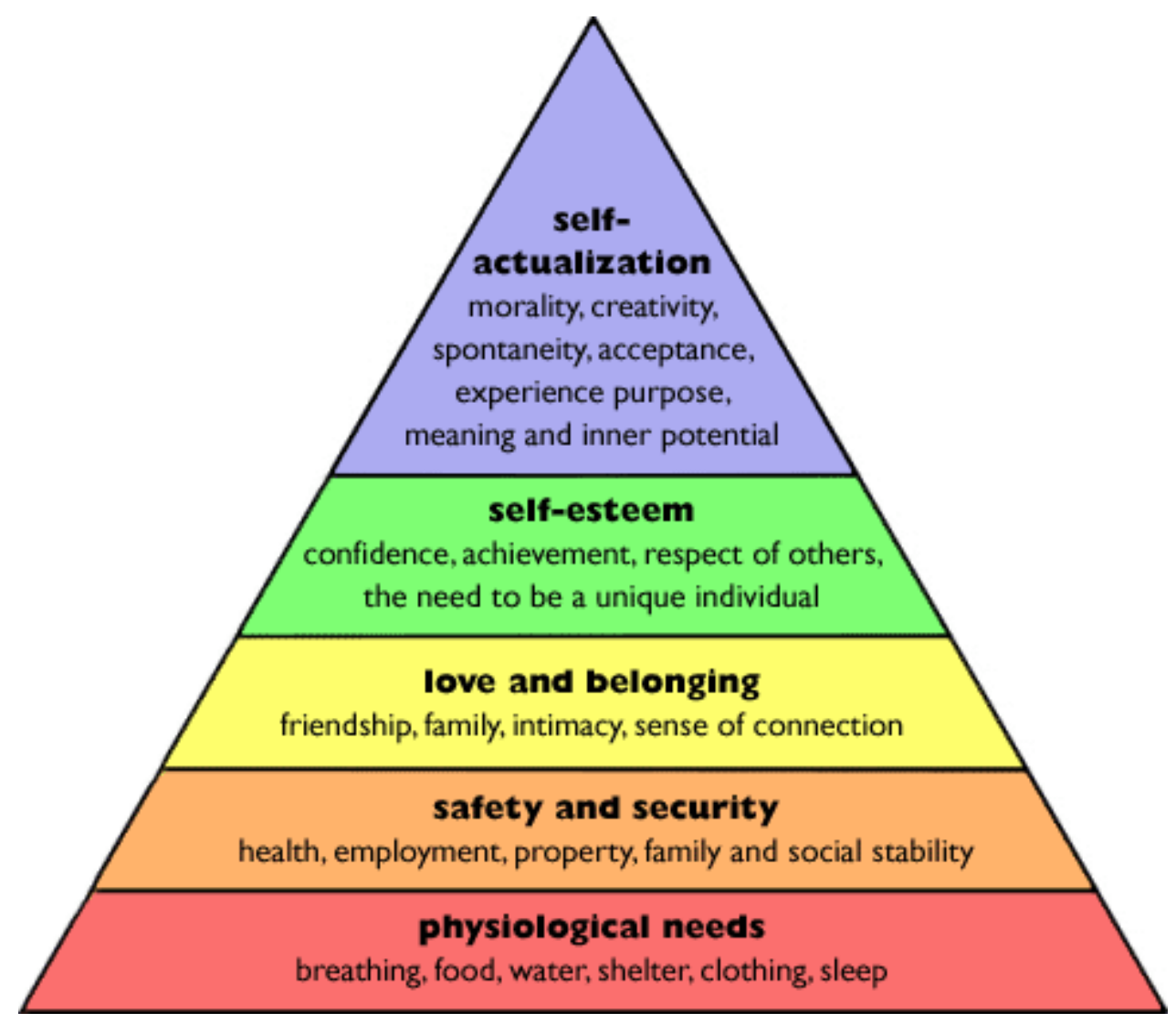

Figure 5: Maslow's Hierarchy of Needs

Though the basis needs approach is not a dominant force in international development, it still shapes thinking. Indeed, there are signs of some revival with all basic needs-related terms showing greater frequency in the post-2015 compared to MDG discourse, and with post-2015 explicitly including the concept of basic needs where the MDGs did not.

But this idea of basic needs does not appear anywhere in WSIS documents and key items that might appear in the two bottom layers - food, resources, water, violence/peace, nutrition, land, sanitation, health, food security, hunger, housing, shelter, employment - are all comparatively under-represented.

This is not to suggest that ICT4D and WSIS should ignore higher level uses of ICT, from learning to culture and ethics. But the foundations must be in place and must, if we believe in Maslow and the basic needs approach, be the first priority that has to be addressed for the world's most vulnerable citizens before any other. Some of the issues such as peace and employment are discussed separately below, and e-health is already a significant area of ICT4D practice including an active WSIS action sub-line ${ }^{10}$.

Higher prioritisation of ICT use in relation to water and sanitation has been mentioned above. Other priorities in this collection include:

\footnotetext{
${ }^{10}$ Health lies only behind environment and poverty in the list of most-frequently discussed development goals in the PTDA documentation. This leads to its moderate under-representation in the WSIS text, but e-health is such a sizeable component already of ICT4D that this moderates any argument for higher prioritisation.
} 
- Food/hunger: ICT applications to strengthen food storage and distribution; improved food security information systems and famine early-warning systems.

- Housing/shelter: use of ICTs to plan, implement, monitor and evaluate housing projects, and short-term shelter projects e.g. those relating to disasters.

- Land: use of ICTs in relation to land degradation, land management, and land rights and tenure.

\section{C3f. Economic Development: Growth, Jobs and the Digital Economy}

Growth and jobs are key elements in the post-2015 agenda. There is a long-standing and ongoing debate about the relationship between economic growth and international development (e.g. Seers 1969, Nafziger 2006). Within this debate a fairly clear trend can be detected: "economic growth dominated the development discourse throughout the 1970s, 1980s and early 1990s." (Rea 2011: 6). Growth then slipped down the agenda, a fade cemented within the MDGs which had no growth-related targets and only one of more than 60 indicators incorporating growth. However - impelled by the 2008 financial crisis in the West and political instabilities in other parts of the world - "economic growth is once again emerging as the dominant approach to development" (Roseveare 2011: 3), with increased presence within the post-2015 agenda compared to the MDGs.

This agenda could be reflected in a couple of the WSIS C7 action sub-lines - e-business and e-agriculture - but in practice has tended to remain confined within a single sub-line on eemployment. As in ICT4D overall, it has far too low a profile and it has been far too narrowly-conceived: in the May 2014 WSIS Vision (WSIS 2014b) it boils down to just three elements - online recruitment portals, teleworking, and ICT training. ${ }^{11}$

ICT4D needs to link to the growth and jobs agenda in a much larger and much more direct manner around ICTs and income growth, ICTs and productivity, and ICTs and job creation. ICTs have a vital, central role in all of these in the $21^{\text {st }}$ century but you would sometimes be hard-pressed to notice from the ICT4D domain. True, evidence is only slowly emerging as ICTs diffuse in developing countries, but there is now sufficient weight to guide priorities including a substantial reworking and revitalisation of the WSIS e-employment action subline.

The link between ICTs, growth and jobs will be seen in two different areas that make up the digital economy (Narasimhan 1983). First, "intensive" applications of ICT where the technology is used to intensify an existing area of economic activity, i.e. all those sectors which existed prior to ICTs. Second, "extensive" applications of ICT where the technology is used to extend the range of economic activity, i.e. creating a new ICT-based livelihood that did not exist prior to ICTs. The extensive activities, together, make up the ICT sector.

\footnotetext{
${ }^{11}$ Related terms 'entrepreneur' and 'enterprise' are over-represented in WSIS, in part due to the small base of about ten mentions each in PTDA text. The difference can be said to reflect a welcome recognition within WSIS and ICT4D more broadly of the role of ICTs in assisting particularly small/micro-enterprise, and women's entrepreneurship (a focal initiative within WSIS, which also helps explain the textual over-representation). But even this needs to be more directly connected to growth, productivity and jobs. Over-representation of 'competit*' was even less useful as a guide, with only four mentions in PTDA text.
} 
It is not clear that ICT4D stakeholders really understand just how big the ICT sector already is in developing countries, with millions of mobile-related jobs and hundreds of thousands of other ICT-related jobs created to date; just how much bigger it will become; and just how different digital microenterprises are (e.g. UNCTAD 2010, UNCTAD 2012). Have they also recognised that digital innovation and digital entrepreneurship are already burgeoning realities within poor communities; requiring new intersections of ICT, enterprise, and innovation policies?

The ICT sector particularly and to some extent the wider digital economy are strong good news stories which - thanks to new business models such as mobile money services and impact sourcing (Foster \& Heeks 2013, Heeks 2013b) - are increasingly reaching down into poor communities to create development benefits via growth, income and jobs. ICT4D overall and WSIS in particular need to be doing more to highlight, support and strengthen this aspect of practice.

\section{C3g. Accountability and Transparency}

The general concept of openness is already well-, even over-, represented in ICT4D/WSIS dialogue and perhaps in danger of becoming over-used. But a specific, data-oriented view of openness - "Open development is about making information and data freely available and searchable, encouraging feedback, information-sharing, and accountability" (World Bank 2014) - may require greater attention. This data-oriented view links openness specifically to transparency, accountability and the fight against corruption. All of theseespecially transparency and accountability - show a very significantly-increased profile within the post-2015 agenda, and a significant under-representation within ICT4D as reflected in WSIS.

Their connection to information systems is summarised in Figure 6 (Heeks 2013c (IS = information system)), which shows how flows of data from a development process (e.g. the activities of a potentially-corrupt public official) can support stages of reporting, transparency and accountability ${ }^{12}$.

\footnotetext{
12 Transparency and accountability often seem to be treated synonymously but, as can be seen, they are different. Where transparency allows a recipient to monitor the performance of a development process and evaluate it against some pre-set benchmark, accountability goes further by permitting the recipient some mechanism of control (e.g. reward or punishment) over the source.
} 


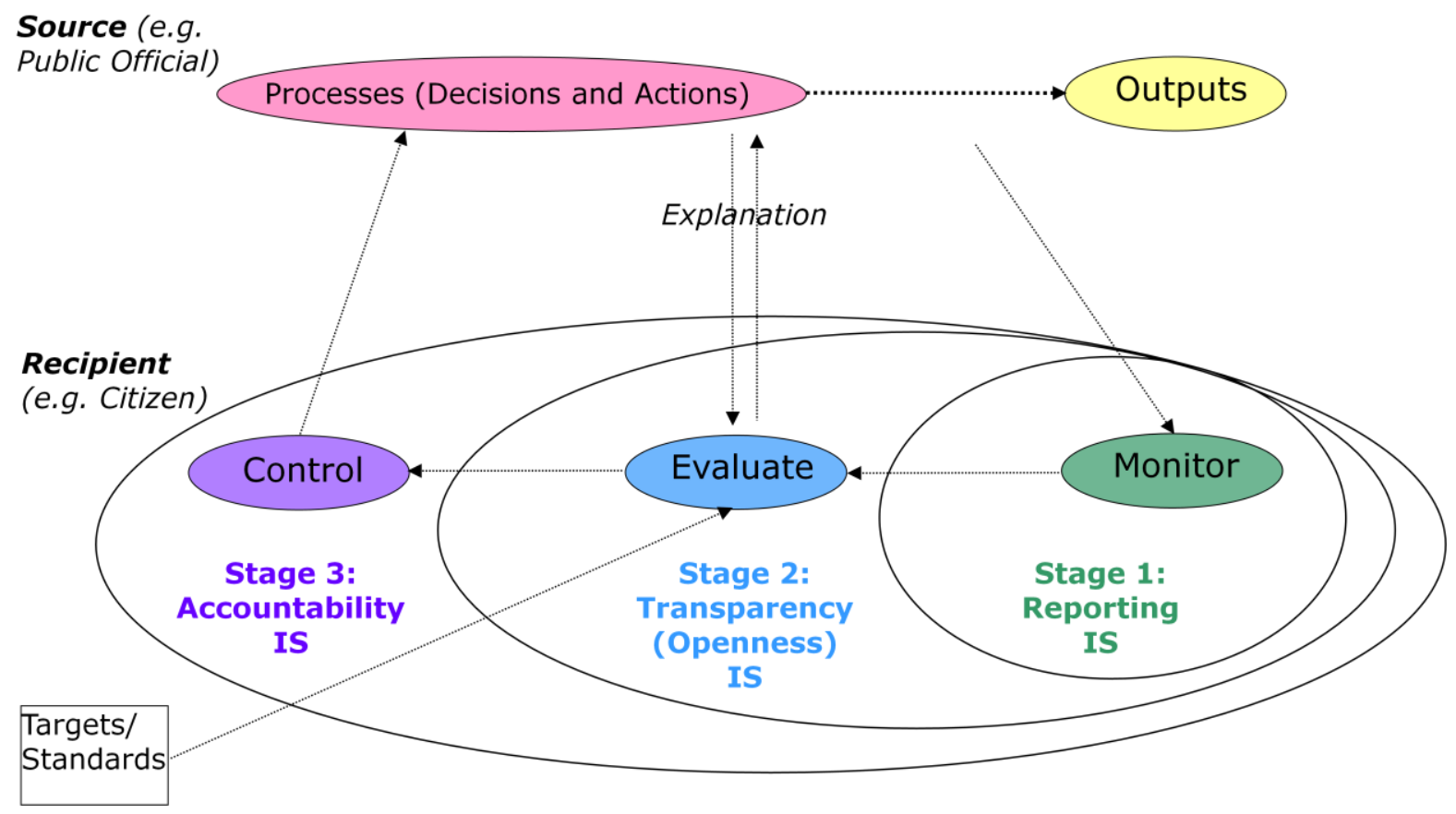

Figure 6: A Data-Oriented View of Transparency and Accountability

ICTs have a vital role to play here in improving the data flows shown in Figure 6; particularly in delivering transparency/openness. There is a missed opportunity to date in explicitly highlighting ICTs' role in combating corruption. But future efforts will most likely be hitched to the "open data" bandwagon. This has most closely been associated with open government data (Davies et al 2013). However, open data initiatives and improvements in transparency and accountability can apply equally to private sector firms, markets, and NGOs (ibid.). Indeed, while there remains an important open government data ICT4D agenda, one could readily argue that the more neglected area lies in connecting ICTs, openness and these latter development stakeholders.

\section{C3h. Cross-Border Flows}

Globalisation - partly facilitated by ICTs - has meant increasing global connections and increasing global flows of labour, of capital, and of goods and services. As the post-2015 agenda recognises, this is only going to accelerate in future. Yet, and despite the integral and growing role of ICTs in most cross-border flows, this is not an issue that has figured very much within the ICT4D field. There needs to be a higher profile for policy and projects relating to:

- ICTs and migration: use of ICTs to support immigrant and emigrant populations, including separated families (reinforcing the family stability that appears in the second level of Maslow's hierarchy: see Figure 5).

- ICTs and trade: use of ICTs to enable international trade. This does appear as part of the WSIS e-business action sub-line but needs greater weight. There is significant use of ICTs in trade (e.g. van Stijn et al 2011) but it has unevenly-benefitted the global North, and it needs to be reoriented to ensure it does not perpetuate or even exacerbate an unlevel playing field (Murphy et al 2014). This application area could also be more 
explicitly acknowledged as part of the ICT4D domain: it was previously (e.g. Mansaray 1992) but this inclusion needs to be revived.

- ICTs and investment: was discussed above under development finance.

\section{C3i. Peace and Security}

Since the Second World War, there has been an ongoing (albeit uneven) trend for a decline in the number of wars and war deaths including a clear decline from the 1990s to the 2000s (Pinker 2011). There is now "more violence within nations than between them", with some signs that insecurity slightly increased during the 2000s (Chalabi 2013, Hewitt et al 2012). Thus discussion of wars, conflict and humanitarian issues declines quite significantly within the post-2015 texts but discussion about violence and security greatly increases; the latter not quite offsetting the former. The overall topic is under-represented in the ICT4D agenda $^{13}$.

There is cyber-security activity in developing countries but this still needs to be significantly stepped up (Burt et al 2014, Osei-Bryson \& Vogel 2014). And this is another example where the agenda needs to break out of the ICT4D bubble of cyber-security to provide equal weight to uses of ICT in mainstream peace and security, across the cycle from insecurity through conflict to post-conflict reconstruction, reconciliation and peacebuilding; from the micro of violence within households to the macro of regional warfare; and bringing in issues from application design and implementation to strategic and policy matters.

\section{C3j. Urban Development}

This topic did not show a particularly dramatic rise in the post-2015 agenda and its overall presence there is relatively low compared to other development issues. However, it is explicitly flagged in post-2015 documents (e.g. HLP 2013, SDSN 2013). And we have the demographic certainty that urban populations are rising: the global tipping point of greater urban than rural population was reached in 2008; that point will be reached for developing countries by 2030; and poverty and many other development challenges are necessarily rising faster in urban than rural areas (Beall et al 2010).

Simultaneously, while there is of course plenty of ICT4D activity in urban areas, there is very little that explicitly links ICT to the particular factors and priorities within the urban development agenda. The WSIS+10 documentation is symptomatic: there is close to zero recognition of the growing role and importance of cities in the development process. The only real mention of 'urban' and 'cities' is in relation to urban-rural digital divides, and there is no place - for example - for ideas about smart, sustainable cities despite the lead WSIS player, the International Telecommunication Union, having a focus group on this very topic.

So ICT4D needs to make a much firmer connection between ICTs and urban development. This means policies singling out ways in which ICTs can support the inexorable growth in urban areas: supporting the creation and implementation of urban strategies, facilitating urban planning - especially slum improvement, improving urban governance and urban

\footnotetext{
${ }^{13}$ Taking the WSIS+10 documentation, the terms 'humanitarian', 'war(s)', 'militar*' and 'terror*' appear so rarely that one should not read anything very much into their frequencies. Of the insecurity-related terms, all are under-represented in WSIS compared to the PTDA except for 'security': as noted in Box 2, this is because the great majority of discussion relates to cyber-security.
} 
design, improving urban ecosystems services and other urban infrastructure including energy and transportation, addressing the specific climate change impacts in urban areas, and contributing to urban job creation (UN-HABITAT 2012). (There can also be converse recognition of the benefits to ICTs - such as the ICT sector - of urban growth and development.)

Tagging all this with the "smart, sustainable cities" label seems appropriate though within WSIS itself, if there can be an action sub-line on e-agriculture, then one would argue there should also be one on "e-cities".

\section{C3k. Resilience}

Resilience is that property of a system (which could be a household, community, organisation, nation, etc) which enables it "to withstand and recover from short-term shocks, and to adapt to long-term trends" (Heeks \& Ospina 2013). Given the projected growth in environmental, social and economic shocks during the coming decades and the associated rise in risk (UNDP 2011, WEF 2013), resilience will become increasingly important if development trajectories are to move forwards rather than slipping backwards. Because it is potentially so foundational to a $21^{\text {st }}$ century view of development, not only will resilience be reflected in the post-2015 framework but it is already the basis for a number of development initiatives: Rockefeller and the UN system both have Resilient Cities initiatives; Oxfam and the World Food Programme run the R4 Rural Resilience Initiative; the EU is funding the RESILIENT project; DFID has set up an NGO group on resilience; and so on.

Resilience is often associated with the environment and sustainability agenda. However, it has outgrown its environmental (climate change/disasters) roots to be seen as a crosscutting property that all development systems - from individuals and households through communities and organisations and value chains to cities, regions and nations - require. And it has outgrown its sustainability roots to be seen as a property to help systems not only sustain but also transform. It has thus developed sufficient momentum to justify a specific presence in this discussion.

Resilience has risen so recently and so sharply up the development agenda that it is no surprise that ICT4D and WSIS have been left trailing: bar one (encouraging) mention under e-agriculture in the WSIS vision materials, the only connection made in WSIS documents or in wider initiatives is to the resilience of ICT infrastructure itself ${ }^{14}$. Certainly ICT4D must do more in future to make its own digital systems more resilient but, once again, the core imperative is to break out of the ICT4D bubble and find ways to use ICTs to make those development systems - listed above - more resilient (Ospina et al 2014).

The first step must be foundational work on understanding the connection between ICTs and resilience: developing tools and metrics; measuring how ICTs impact resilience (e.g. Heeks \& Ospina 2013); and understanding how best to make ICT-based systems more resilient to external threats (Theron \& Bologna 2013). In toto, while there is a significant

\footnotetext{
${ }^{14}$ Resilience-related terms are also under-represented in WSIS+10 documentation, with little sense yet of how a more resilient approach to ICT4D will help address: vulnerability, risk, crises, fragility, shocks, volatility and uncertainty.
} 
connection in all this to sustainability informatics, the specific issue of resilience informatics ${ }^{15}$ will need to form its own particular sub-domain of ICT4D activity.

\section{C3I. Inclusive Development}

There have been growing concerns that improvements in overall national-level development indicators are masking expanding intra-country inequalities, and that higher inequality - as well as being inherently problematic - will retard development in the long run (e.g. Wilkinson \& Pickett 2010, Stiglitz 2012). There is debate on the extent to which the creation of inequality is inherent to particular development models. However, there is a strong association of the neo-liberal model with formation of inequality (e.g. Lazzarato 2009), and hence sometimes an assumed requirement for alternative approaches to development in order to address this issue.

The key terminology for that alternative approach is "inclusive development"; meaning development that provides opportunities and benefits for all, including those who have to a relative or absolute extent been excluded by development to date (e.g. Rauniyar \& Kanbur 2009). Its incursion into the development debate can be seen by the $1000 \%$ rise in discussion of inclusion/inclusivity and exclusion in the post-2015 agenda compared to the MDGs.

The strongest connection between ICT4D and inclusion has been action taken on the digital divide. This has been a cornerstone of ICT4D-related policies and programmes, and hence of WSIS activity. While there is no explicit action line on this, it is an explicit component of a number of action lines; a cross-cutting thread that is discussed throughout WSIS+10 documentation ${ }^{16}$. Digital inclusion is also a continuing theme with recognition that digital divides - note the plural - remain and develop: hundreds of millions have no mobile phone access; the Internet divide encompasses many more; the broadband divide is emergent; and the technology-access divide is far outstripped by the effective-information-use divide (e.g. Ragnedda \& Muschert 2013).

There are specific digital divides that impact particular groups: women, youth, the disabled, ethnic minorities. At least on the basis of the text analysis used here, youth and the disabled have a prominence at least commensurate with their place in the post-2015 agenda. This is not so true for ethnic minorities and women. Women's development is liberally discussed in WSIS, and there are many examples of ICT4D initiatives aimed at gender inequalities. However, there is still a small lag behind the level of debate within post-2015.

But as with other topic areas, the greater challenge is to break out of the ICT4D bubble - to do more than just address digital divides - and to engage with the breadth of inclusive development. In part this will relate to language - not just the gesture of adding the "inclusive" label but taking on the true meaning of concepts like inequality and vulnerability,

\footnotetext{
${ }^{15}$ The terminology to use here is important since it will shape perceptions about the agenda. "e-Resilience" has been used but that, along with "digital resilience", may give the impression of being technocentric and internal to the ICT sector instead of reaching out to serve broader goals. "ICT4R" could well be most appropriate.

${ }^{16}$ With massive over-representation of terms like 'divide(s)' and 'access*' in WSIS compared to the PTDA.
} 
rights and justice. All these are currently under-represented and one could draw on the latter to argue for greater engagement of ICT4D with rights-based approaches to development, and the notion of social justice.

But it will also mean developing action agendas around related mechanisms - such as social protection - and around each fraction of inclusive development: inclusive growth, inclusive health, inclusive education, etc. One fraction of especial relevance to ICTs is "inclusive innovation" - the process and system by which new informatics-based goods and services are developed by and/or for excluded groups. Inclusive informatics innovation systems must be understood, identified, and encouraged.

Another relevant fraction will be "inclusive business models" given that ICTs are increasingly enabling those within base-of-the-pyramid communities to participate in business value chains. This may develop initiatives using ICTs to support inclusive value chains; for example, extending the idea of "fair tracing" (Light 2010). Alternatively, it may support ICTenabled business models such as impact sourcing - the outsourcing of ICT-related work to excluded and disadvantaged groups that creates new jobs, incomes and skills (Heeks 2013b).

\section{C4. Transformative Development and Development 2.0}

In putting together the priorities listed above, I have thought about the implications of all terms that were less than to -0.5 or more than +0.5 in Table $\mathrm{C}^{17}$. But now one term remains to discuss - 'transform*' - a term which appears roughly four times more often in the post-2015 literature than it does in the selected sample of ICT4D documentation.

As noted in Heeks (2014a), there is a leitmotif of transformation within the post-2015 agenda to date; a belief that the incremental developmental changes achieved to date will no longer be sufficient in the remainder of the $21^{\text {st }}$ century; and an aspiration for a stepchange in approach. The initial foundation for the post-2015 agenda (UN 2012:i) states "Business as usual thus cannot be an option and transformative change is needed", and its successor (UN 2013:1) speaks of the need to facilitate "transformational change". Going further, the High-Level Panel report (HLP 2013) puts a central emphasis on five "transformative shifts" that need to drive the post-2015 agenda:

"1. Leave no one behind. ...

2. Put sustainable development at the core. ...

3. Transform economies for jobs and inclusive growth. ...

4. Build peace and effective, open and accountable institutions for all. ...

5. Forge a new global partnership."

What this notion of transformation means in practice is rather fuzzy. Sometimes it seems to mean just more of what is already being done - pushing on with the MDG agenda, with openness and accountability, with multi-stakeholder partnerships. Sometimes it means not just doing more but doing it somewhat differently e.g. to include those who have hitherto

\footnotetext{
${ }^{17}$ The only three terms which, as a result, did not find an explicit connection with the discussion above were 'system', 'social' and 'institution'; seen as too generic to provide clear guidance for future action.
} 
been excluded. And at other times there is more a sense of step change e.g. in seeking to make development sustainable for the future or, very occasionally, in challenging the current structures of international development (though with no detail on what such a structural transformation might entail).

What does all this mean for ICT4D and for WSIS? Given the under-representation shown in Table C1, it suggests ICT4D needs to be doing more to connect ICTs and the transformation of development. There is already a general orientation for such activity - development 2.0 - defined as "new ICT-enabled models that can transform the processes and structures of development" (Heeks 2010b:1) ${ }^{18}$. But defining the content of a development 2.0 policy and practice agenda more precisely will be difficult owing to the fuzziness of the underlying concept of developmental transformation.

First, there is the threshold problem - when is a change sufficiently large to be classified as 'transformative' as opposed to just 'incremental'? Second, there is the direction problem transformation of what? Of context (e.g. structures)? Of inputs (e.g. goals, visions, aspirations)? Of processes (e.g. business models, partnerships)? Of outputs (e.g. inclusion, sustainability)?

We thus have problems defining transformation in terms of both extent and content. Heeks' Development 2.0 definition above was a mix of process and structure; identifying three "potentially-transformative" ICT-enabled models - direct development, networked development, grassroots development. So it misses some possible aspects of content, it has no clear answer to the threshold problem, and it lacks a strong conceptual foundation (though might seek the latter either in the ideas of complex adaptive systems or in the ideas of sustainability).

Once we have worked to understand transformation and Development 2.0 better, there will be three further foundations needed in order to define the policy/practice agenda:

- Ecosystem: who and what makes up a Development 2.0 ecosystem? A Development 2.0 ecosystem is that combination of organisations (government, private sector, $\mathrm{NGO} /$ community, etc); institutions (policies, culture, etc), technologies (standards, infrastructure, architecture, applications, etc), and other resources (money, skills, etc) which allows ICTs to have a transformational effect at anything from district to regional to national to international level.

- Business Models: what are the new ICT-based business models that provide for a transformative developmental impact? In many ways, the Development 2.0 business model is the organisational equivalent of the higher-level ecosystem; covering organisational strategy, structure, process and value chain from suppliers to clients. Despite the 'business' language, Development 2.0 models can be identified in public, private and NGO sectors (ibid.).

- Facilitation: what processes and capacities are needed to facilitate emergence and successful implementation of Development 2.0? This can be answered for both broader ecosystems and narrower business models. It can encompass a focus on structures, on processes, and on the agency of individuals or groups.

${ }^{18}$ ' $2.0^{\prime}$ itself appears nowhere in the PTDA, and just ten times in the WSIS+10 papers, relating to Web 2.0. 
Both Heeks (ibid.) and Thompson (2008) identify ICTs as the mechanism that will enable and might even drive - some transformation of development. Thus, Development 2.0 should clearly be part of the future ICT4D agenda, and should be a priority. Hence, its inclusion in Table 2. But foundational work is needed to conceptualise the meaning of both developmental transformation and Development 2.0, and the constituent parts of Development 2.0, before a clear agenda for action can emerge.

\section{C5. The Future of ICT4D and WSIS: Structure, Process and Vision}

\section{C5a. Structure: Mainstreaming or Sidestreaming ICT4D?}

Around the time of the MDGs, ICT4D became the focus for a critical mass of activity; a "sidestreaming" approach that saw specialist ICT4D units arise in a number of international and national organisations. Post-WSIS, this was largely mainstreamed with specialist units being disbanded or contracted, and ICT4D expertise seen as diffused into the main development sectors. There is a logic to mainstreaming - if done right - in ensuring integration of ICTs into a broad range of development goals.

But there are also many dangers of just mainstreaming (Heeks 2010a): you lose the focus for learning about ICT4D; you hide or downplay technological innovation which can be a source of motivation and hope, and a lever for change; you lose sight of the ICT sector and digital economy roles in development; you silo ICT into individual development sectors and thus miss the technology's cross-cutting, integrative capabilities; and there is no Development 2.0 or other vision for ICTs as a force for transformative change.

So alongside mainstreaming, there needs to be some sidestreaming: retaining and supporting specialist ICT4D units within ... the UN system overall; individual UN organisations; international development agencies; national development agencies; national governments; international NGOs; etc. But ICT4D seems to spend more time making arguments for mainstreaming than for sidestreaming: in the WSIS documentation, mainstreaming is mentioned on a fairly regular basis but the need for sidestreaming - very much present if one cared to draw it out - is only implicit.

The case for specialist concentrations of expertise will require evidence of the past benefits of, and continuing future necessity for, sidestreamed structures at all levels within development. That should associate the value of sidestreaming just identified - learning, motivation, hope, change, ICT-based livelihoods, integration, transformation, etc - not just with the positive impacts of ICT4D but also the negative: as development becomes evermore digital, we will require a focused effort to address its dark side.

As noted, this applies at various levels but the structuring at the level of the UN system mirrors that one would find at the level of individual countries and organisations. Essentially you have a technology-focused structure - the ITU in the case of the UN; equivalent to a Ministry of ICT at national level or the IT department at organisational level. Its future is never in doubt and it remains the bastion of sidestreaming. But these structures 
have a problem: they are full of engineers with a techno-centric worldview who find it difficult to understand development language and concepts.

We can characterise the issue in terms of the ICT4D value chain (see Figure 7; adapted from Heeks 2010c). Technical structures are good at dealing with the technical components of 'readiness', and the technical deliverables of 'availability'. But they are not so good at dealing with the non-technical elements of both stages, nor with the issues of 'uptake' and 'impact'. That would be a problem in itself but it is exacerbated because, over time and as ICT diffuses ever-further into international development, there is a shift in focus from just being concerned about readiness and availability to being equally - if not more - concerned with uptake and impact (see Figure $8 ;$ ibid.). Although a very rough-and-ready calculation different selection of terms could produce a different result - there are signs from the figures presented in Appendix D that WSIS still retains a significant 'upstream' focus on readiness and availability as compared to the 'downstream' issues of uptake and impact. This suggests it is being restrained somewhat by an overly-technical focus, which may arise from the domination of overly-technical structures ${ }^{19}$.

\footnotetext{
${ }^{19}$ As another example, the terms 'standards' appears more often than the term 'poverty'.
} 
Enablers

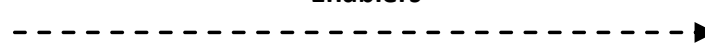

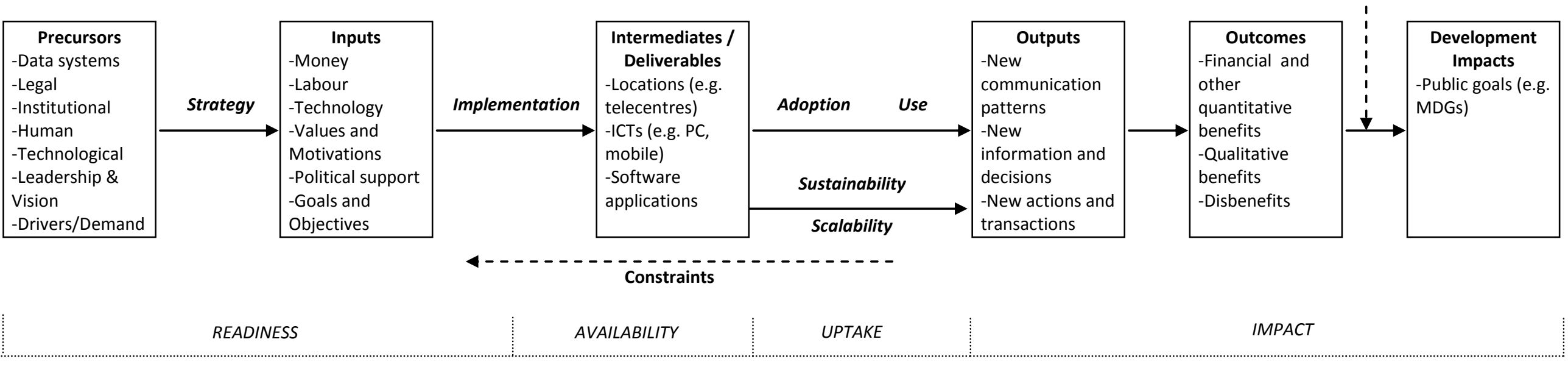

Figure 7: The ICT4D Value Chain 


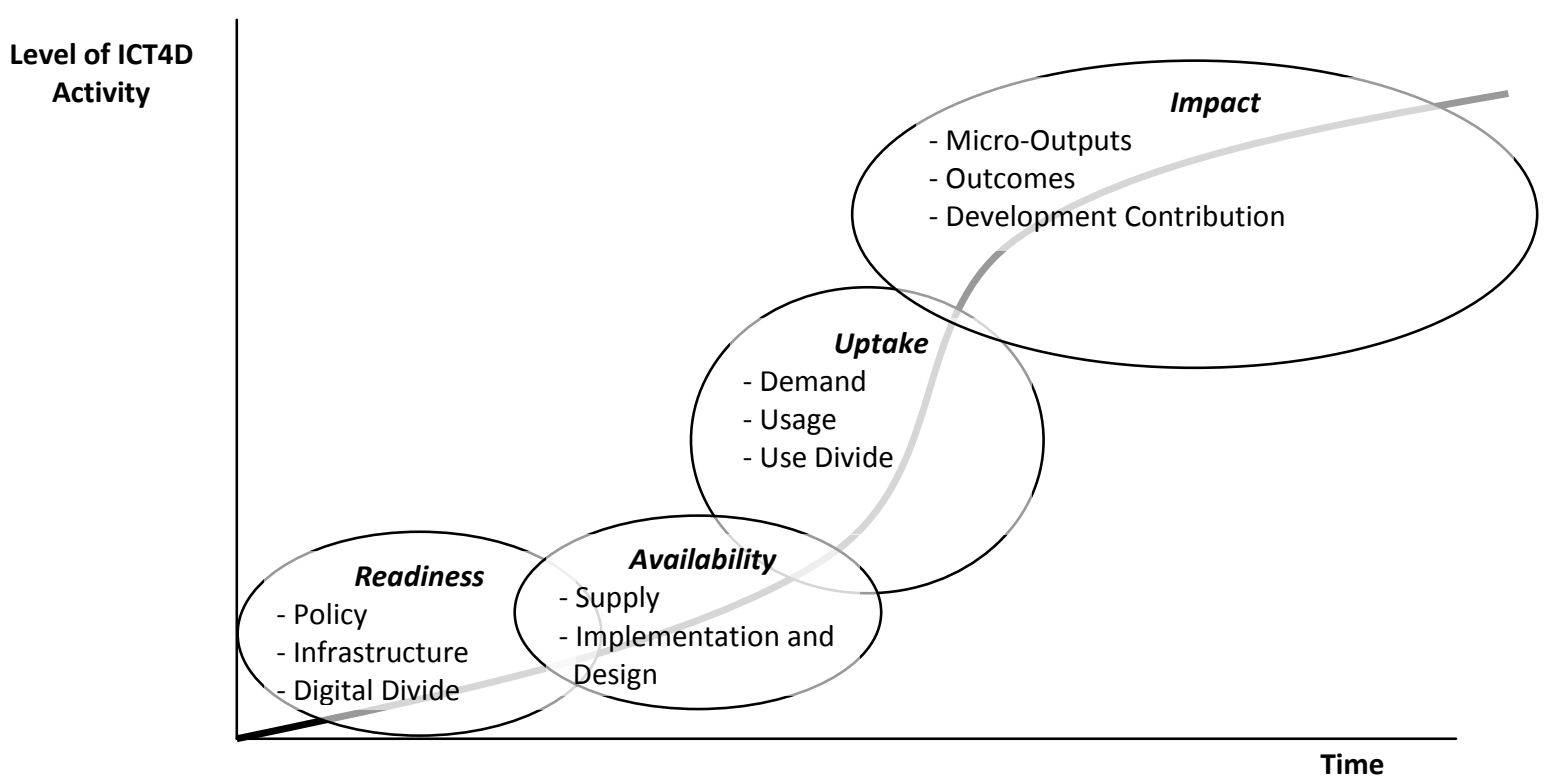

Figure 8: Changing Focus of ICT4D Priorities Over Time

The solution here is that, over time, one places less emphasis on technical personnel and technology-dominated structures, and greater emphasis on ICT4D hybrids: socio-technical people and structures who combine an understanding of informatics (data, information, ICTs, information systems) with an equal understanding of development. In theory, the UN system has this via the UN Group on the Information Society, which was set up in 2006 in the wake of WSIS 2005 to draw together those with ICT4D interests and responsibilities from across the UN system ${ }^{20}$. However, the extent to which UNGIS members are actually hybrids is unclear; it is currently chaired by the ITU which must shape its worldview; and more generally, UNGIS seems to have limited power and reach in part due to its lack of independent resources.

So what of the future for ICT4D structures in the UN system? One could argue for a hybridisation of the ITU: a broadening of its scope to turn it from a technical into a sociotechnical organisation that can cover all parts of the ICT4D value chain. But that could be self-defeating in terms of politics and impact: it could create an ICT4D silo that was isolated from development; all sidestream and no mainstream. And it would also be impractical given the focus and interests of ITU's membership. Far better for ITU to stick to the readiness and availability issues that it does best - infrastructure, standards, access, bridging the digital divide - and instead to strengthen UNGIS with its own clear and independent mandate, funding, and secretariat. It would also make sense to draw other and emergent UN actors into UNGIS, such as Global Pulse.

\footnotetext{
${ }^{20}$ In the wake of the demise of the UN Global Alliance on ICT for Development (UN GAID), UNGIS is the only cross-UN ICT4D focal structure, complementing the cross-UN ICT4D focal process of WSIS. UNGIS was initially created to facilitate WSIS but, in 2009, its mandate was extended to a somewhat broader ICT4D facilitation role (UNCSTD 2011).
} 
This would create an appropriate ICT4D structure within the UN system (see Figure 9) with ITU providing the broad foundation of ICT expertise, and UNGIS providing the hybrid spearhead that connects out to all of development.

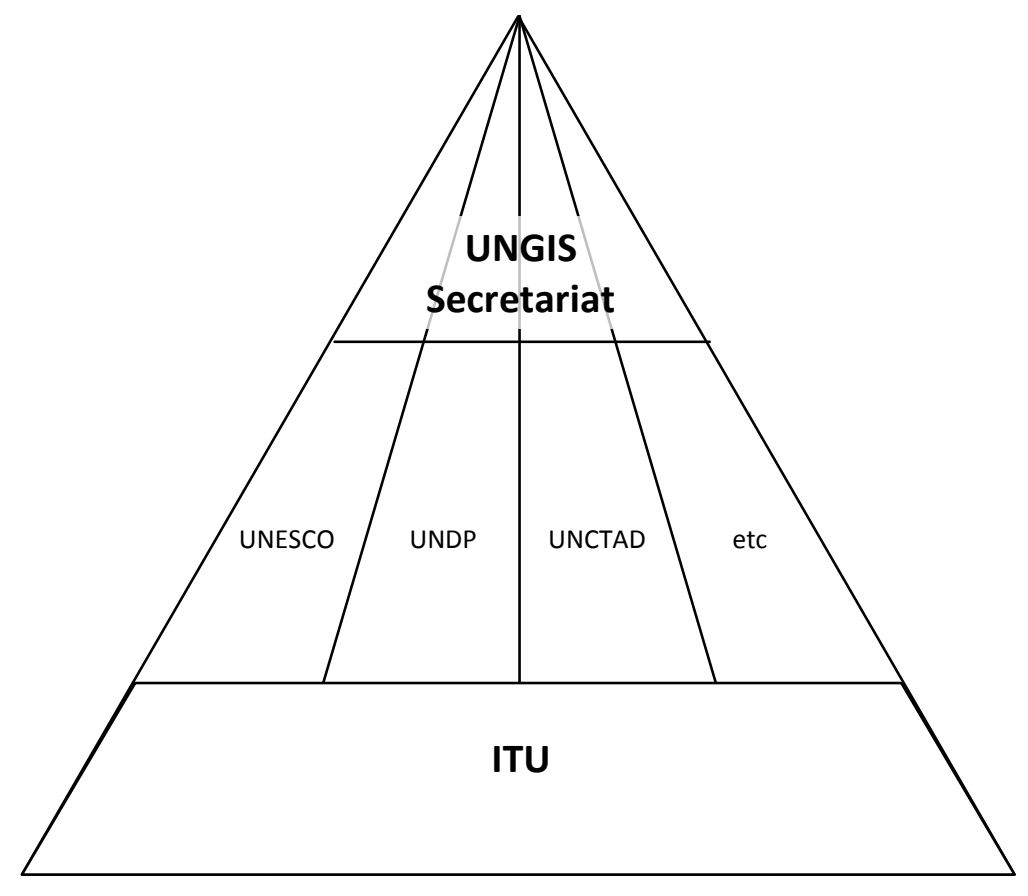

Figure 9: Structuring ICT4D Within the UN System

This would also ensure one further essential aspect of ICT4D's future within the UN system, which is the continuation of WSIS beyond 2015.

\section{C5b. Process: Continuing Multi-Stakeholder Participation}

ICT4D as a domain has certainly adopted the language of multi-stakeholder participation but has gone beyond just rhetoric in two ways, as illustrated by analysis of real-world ICT4D policy-making (Bardelli-Danieli 2011). First, by involving participants from a variety of sectors in the planning and design of policies and programmes. Second, by taking on the worldview of multi-stakeholder participation such that it becomes the only conceived benchmark for ICT4D processes. There is some hope, then, that ICT4D adheres to the maxim that one can only create inclusive outcomes via inclusive processes.

WSIS itself fits this mould. Although I write as an occasional observer/participant of WSIS, this perspective and more analytical sources (e.g. UNCSTD 2011), both suggest WSIS appears to be an inclusive process that seeks to live up to its ambitions of multi-stakeholder participation. Through analysis of submissions and documentation, one can identify a leaning towards international organisations and governments, some civil society involvement, and much more limited roles for business and academia. Thus there is scope for broadening participation, and the bureaucracy and internal politics of the UN system play their role dampening external influence. Nonetheless, overall, ICT4D and WSIS processes can be awarded at least a glass half-full status. 


\section{C5c. Vision: Where is the Compelling Narrative?}

ICT4D drew attention, money and other resources at the turn of the century because it was associated with a compelling narrative. Albeit via a variety of terms, we foresaw the creation of an information society in developing countries; delivering the e-fruits of the global North to the global South.

At present, we have no such ICT4D narrative for post-2015 development. The technology has fragmented with ICT4D struggling to keep hold of mobile, broadband, cloud, social media, smartphones, etc. The development goals and sectors that ICT serves are subfragments within economic, social, political and environmental fragments.

Having never really gone away, it is hard for ICT4D to really reinvent itself with a reinvigorated sense of what an "information society" is and why it matters. Current WSIS+10 visions certainly have little to offer (WSIS 2014b). There is no defined core of an information society, just a sweeping up of the many fragments in the hope they might amount to something worth pursuing. The notion of an information society is qualified: in a number of places it must be "inclusive"; at one point it must be "people-centric, inclusive, open and development-oriented" (did someone forget to add "sustainable" to that list?).

The erosion of vision is in some ways understandable because ICT4D stood well ahead of actuality in the early 2000s, offering a clear and different future destination. Over the years, reality in developing countries has started to catch up but WSIS has not maintained its headway: it has moved from casting visions to reflecting realities. WSIS has also fallen victim to a path dependency that keeps it within existing tramlines: a future of the same old action lines, and a conservatism that leads to repetition of increasingly-stale incremental formulations instead of embracing transformative new thinking. If path dependency is typical of institutionalised processes then fragmentation of core concepts is typical of multistakeholder processes: it is easier to keep adding phrases to please particular constituencies. But it means "information society" resembles the mule in Buckaroo increasingly over-laden, and with the only solution that it must throw off all of these loads and boil down to a more singular and coherent vision.

ICT4D could try to join another's army, looking for a central role within the core narratives of post-2015 development. But those narratives are not yet clear - perhaps sustainable development; perhaps inclusive development - and narratives of "sustainable informatics" or "inclusive informatics" might give ICTs a marginal not central role in development (see also Box 5). They would, nonetheless, be worth developing: as noted above the questions "where do ICTs fit into a sustainable development agenda?" and "where do ICTs fit into an inclusive development agenda?" remain unanswered. 
Box 5: “e-X“, “m-X”, “ICT4X”, “Informatics4X”, “X Informatics”, “Digital X”, “X 2.0”, etc

An ongoing theme in this review is the importance of language and labels. Among the multiplicity on offer, such as those in this Box's title, I don't have any specific solutions to offer but will note a few principles:

- Clarity: does the label make sense to, for example, a mainstream development project manager? You're allowed one go to explain it. If it doesn't stick after that; forget it.

- Techno-centricity: how technology-focused is the label? Yes, it's a problem if we are too focused on the technology and so forget the, arguably more important, human and contextual issues. But equally we must not lose sight of the technology which is the raison d'etre of the whole domain. That's why I like "informatics" which steers well between these two. Likewise, "information society".

- Scope: what is covered by the label? " $m-X$ " labels such as " $m$-money" cut out a significant part of the ICT field; any " $X 2.0$ " definitions that only limit themselves to association with Web 2.0, would do the same.

- Purpose: is it clear what the technology is for? "ICT4D" scores well here: the technology is not an end in itself but a means to a wider purpose. In general, then, the "...4X" formulation - "...4H" (health), "...4E" (education) - helps in this regard.

- Novelty: how new and exciting does the label sound? Humans - perhaps especially modern humans - seem to crave novelty, and habituation to a label weakens its ability to command attention and resources. ${ }^{21}$

ICT4D could try grabbing someone else's flag, claiming the data revolution as its own, and carrying that forward at its head into post-2015 discussions. It won't be a comprehensive narrative, but at least it would be something that smells of fresh paint.

ICT4D might try to develop its own internal narrative. The two candidates so far have barely sputtered, let alone caught fire. "Development 2.0 " - as discussed above, this is the ICTenabled transformation of development processes and structures - remains a marginal concept but one worth further investment given transformative development is a third possible narrative of the post-2015 agenda alongside sustainability and inclusivity. "Open development" has, thanks to IDRC, had more thought and work put into it and - another plus - it reaches out well beyond the technology (Smith et al 2011). But that is also its downside: it does not yet resonate as an ICT- or even informatics-related narrative; and it suffers from conflicting meanings (the World Bank definition of open development offered above is narrowed to open data and its impact on transparency and accountability; IDRC's definition is more ambitious and potentially paradigmatic).

All that can be suggested at present, then, is exploratory moves to look for an overarching narrative. The future role and structure of ICT4D policy and practice may well depend on how far forward those moves are able to explore.

${ }^{21}$ As an example, check the development hype cycle (Algoso 2014). 


\section{Conclusion: ICT4D and WSIS Beyond 2015}

This paper has set out to compare the current and future direction of ICT4D with the coming post-2015 development agenda, to assess how well ICT4D fits with the single best guide to its future context. It has done that via text analysis, taking documentation from the WSIS+10 process as its guide. In doing so, it makes an important assumption that WSIS documents reflect the current content and direction of ICT4D more broadly. There is by no means a perfect fit here - as the example of mobile money illustrated. But the argument here is not that there is a perfect fit, but that there is no other set of text that represents a better fit. So WSIS is the best guide to ICT4D policy and practice that we have.

A core outcome was Table 2 - an analysis-based guide to the main mismatches between the future development agenda and the state-of-play with ICT4D generally and WSIS particularly. These - in descending order from the top - are ICT4D/WSIS' main priorities for additional action and strengthening.

Alongside the need to break out of the ICT4D bubble, there are two other transectional corollaries. First, that the list in Table 2 does not represent the totality of ICT4D priorities; they represent those post-2015 topics which have been most under-represented. Thus work on, for example, ICT infrastructure, ICTs and health, ICTs and education/learning, ethical aspects of ICTs, etc, will need to continue during this period. And there will need to be new work on emerging ICT topics.

Figure 10 attempts to put all this together as an ICT4D priority map. Vertically, it sorts issues in terms of gap and, hence, priority for additional attention: the higher up the diagram, the higher that priority. A number of the items in the upper parts of the diagram could be used as the basis for new or amended WSIS action lines. Laterally, Figure 10 sorts issues in terms of their relation to development (mainly types of goal, including crosscutting, but also including development mechanisms of which ICT itself is one) ${ }^{22}$.

\footnotetext{
${ }^{22}$ This not perfectly done: the ICT issues in the bottom half of the 'political' column probably belong more appropriately in the 'mechanisms' column. The specific label terms have just been chosen to illustrate the variety of possibilities as noted in Box 5. Development 2.0 appears as a dashed box because of the foundational work needed to specify its content and agenda.
} 

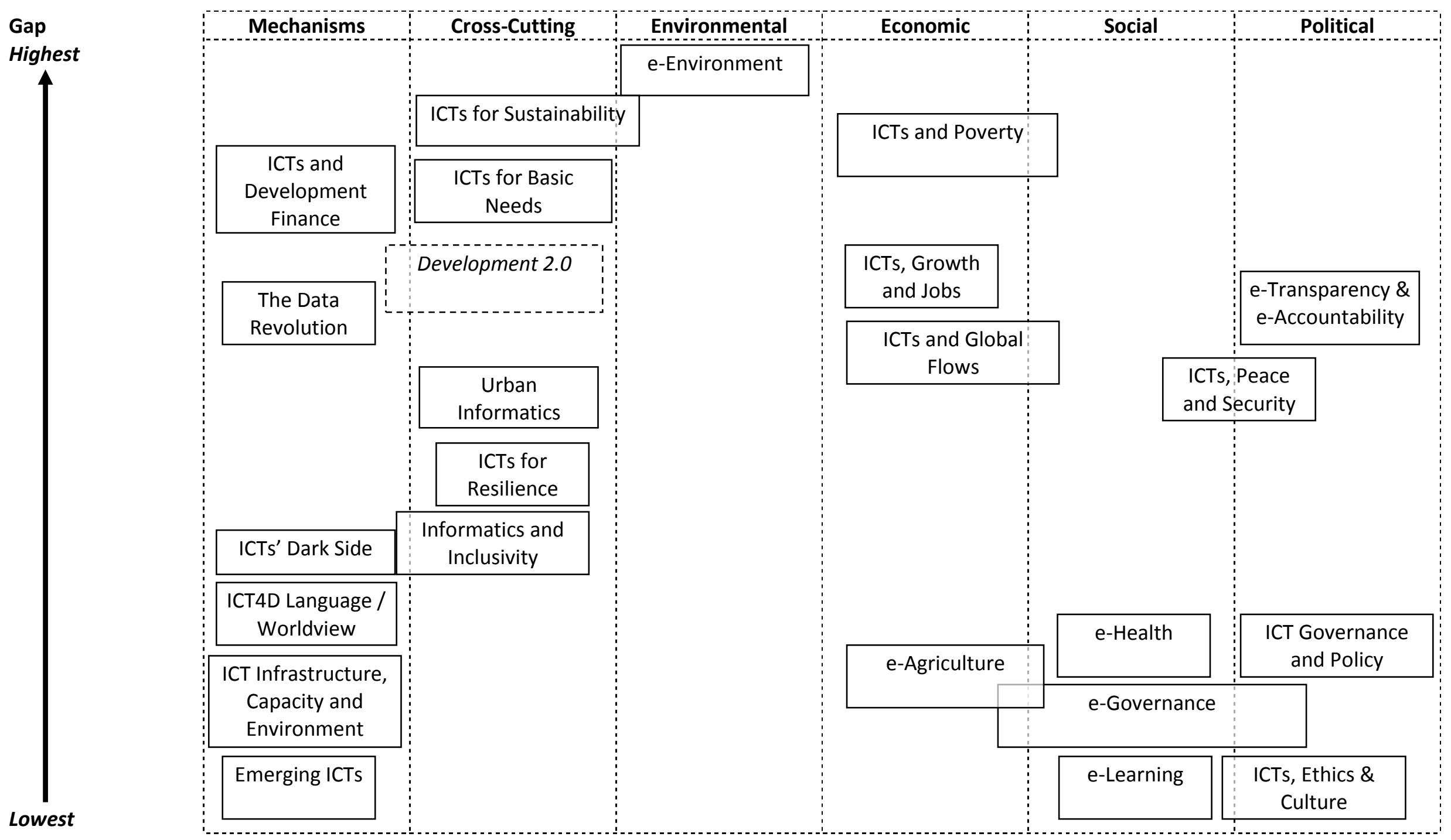

Figure 10: Map of Post-2015 ICT4D Priorities 
The second corollary is the importance of ICT4D continuing to hold a place in the development agenda, in the global development system, in development policy, and in individual development organisations. The $21^{\text {st }}$ century brings with it many uncertainties but one thing we can be sure of: from autonomous vehicles to robots to drones to big data, ICT will play an ever-growing role in human life generally and in processes of socio-economic development specifically. There has to be a mechanism at multiple levels of governance in order to accelerate the good and constrain the bad in what is to come.

One of those multiple levels will be the global level. WSIS has been imperfect but it has also been vital. It is the only lever the world can pull in seeking to shape and control the expanding digital presence in our lives. As this paper argues, WSIS can be improved beyond 2015; it might even be revised and revived. But it cannot be done without. 


\section{References}

Adera, E.O., Waema, T.M., May, J., Mascarenhas, O. \& Diga, K. (2014) ICT Pathways to Poverty Reduction, Practical Action Publishing, Rugby, UK http://idlbnc.idrc.ca/dspace/bitstream/10625/52420/1/IDL-52420.pdf

Algoso, D. (2014) Hype cycle for development ideas: 2014 edition, Find What Works, 2 Jan http://algoso.org/2014/01/02/hype-cycle-for-development-ideas-2014edition/

Bardelli-Danieli, A. (2011) Interpreting ICT Policy Processes in Developing Countries: A Case Study of Uganda, PhD thesis, IDPM, University of Manchester, UK

Beall, J., Guha- Khasnobis, B. \& Kanbur, R. (eds) (2010) Urbanisation and Development, Oxford University Press, Oxford, UK

Boehm, M. (2013) Has job polarisation squeezed the American middle class?, CentrePiece, Autumn, 7-9

Burt, D., Nicholas, P., Sullivan, K. \& Scoles, T. (2014) The Cybersecurity Risk Paradox, Microsoft, Redmond, WA

Chalabi, M. (2013) Global peace index 2013, Datablog, 11 Jun http://www.theguardian.com/news/datablog/2013/jun/11/global-peace-index-2013

Davies, T., Perini, F. \& Alonso, J.M. (2013) Researching the Emerging Impact of Open Data, ODDC Working Paper 1, Open Data Research Network http://www.opendataresearch.org/sites/default/files/posts/Researching\%20the\%20 emerging\%20impacts\%20of\%20open\%20data.pdf

Demerouti, E., Derks, D., ten Brummelhuis, L.L. \& Bakker, A.B. (2014) New ways of working: impact on working conditions, work-family balance, and well-being, in: The Impact of ICT on Quality of Working Life, C. Korunka \& P. Hoonakker (eds), Springer, Heidelberg, 123-141

DI (2013a) Official Development Assistance (ODA) Factsheet, Development Initiatives, Bristol http://devinit.org/factsheet/factsheet-oda/

DI (2013b) Mobilising All Resources to Meet the Post-2015 Goals, Development Initiatives, Bristol http://devinit.org/wp-content/uploads/2013/12/Mobilising-allresources-to-meet-the-post-2015-goals1.pdf

DSD (2014) Working Document for the Eleventh Session of the Open Working Group on SDGs, Division for Sustainable Development, UN Department of Economic and Social Affairs, New York, NY http://sustainabledevelopment.un.org/content/documents/3686WorkingDoc 0205 additionalsupporters.pdf 
ESS (2013) Big Data for Social Good, Engineering Social Systems, University of Harvard, Cambridge, MA http://www.hsph.harvard.edu/ess/bigdata.html

Foster, C. \& Heeks, R. (2013) Innovation and scaling of ICT for the bottom-of-thepyramid, Journal of Information Technology, 28(4), 296-315

Global Pulse (2013) United Nations Global Pulse, United Nations, New York, NY http://www.un.org/millenniumgoals/pdf/GP\%20BackgrounderGeneral2013 Sept2013.pdf

GSMA (2014) MMU Deployment Tracker, GSMA, London http://www.gsma.com/mobilefordevelopment/programmes/mobile-money-for-theunbanked/insights/tracker

Haikin, M. \& Duncombe, R. (2013) A Framework to Assess Participation and Empowerment Impacts of ICT4D Projects, Development Informatics Working Paper 55, Centre for Development Informatics, University of Manchester, UK http://www.seed.manchester.ac.uk/subjects/idpm/research/publications/wp/di/

Heeks, R. (1999) The Tyranny of Participation in Information Systems: Learning from Development Projects, Development Informatics Working Paper 4, Centre for Development Informatics, University of Manchester, UK http://www.seed.manchester.ac.uk/subjects/idpm/research/publications/wp/di/

Heeks, R. (2010a) Mainstreaming ICTs in development: the case against, ICT4DBlog, 30 Oct http://ict4dblog.wordpress.com/2010/10/30/mainstreaming-icts-indevelopment-the-case-against/

Heeks, R. (2010b) Development 2.0: the IT-enabled transformation of international development, Communications of the ACM, 53(4), 22-24

Heeks, R. (2010c) Do information and communication technologies (ICTs) contribute to development?, Journal of International Development, 22(5), 625-640

Heeks, R. (2013a) Development informatics research must stop ignoring ICT's downsides, ICT4DBlog, 23 May https://ict4dblog.wordpress.com/2013/05/23/development-informatics-researchmust-stop-ignoring-icts-downsides/

Heeks, R. (2013b) Information technology impact sourcing, Communications of the ACM, 56(12), 22-25

Heeks, R. (2013c) eCitizens: Connecting Citizens and Government, Centre for Development Informatics, University of Manchester, UK 
Heeks, R. (2014a) From the MDGs to the Post-2015 Agenda: Analysing Changing Development Priorities, Development Informatics Working Paper 56, Centre for Development Informatics, University of Manchester, UK http://www.seed.manchester.ac.uk/subjects/idpm/research/publications/wp/di/

Heeks, R. (2014b) Future Priorities for Development Informatics Research from the Post-2015 Development Agenda, Development Informatics Working Paper 57, Centre for Development Informatics, University of Manchester, UK http://www.seed.manchester.ac.uk/subjects/idpm/research/publications/wp/di/

Heeks, R. (2014c) ICTs and Poverty Eradication: Comparing Economic, Livelihoods and Capabilities Models, Development Informatics Working Paper 58, Centre for Development Informatics, University of Manchester, UK http://www.seed.manchester.ac.uk/subjects/idpm/research/publications/wp/di/

Heeks, R.B. \& Ospina, A.V. (2013) Understanding Urban Climate Change and Digital Infrastructure Interventions from a Resilience Perspective, Development Informatics Working Paper 54, Centre for Development Informatics, University of Manchester, UK http://www.seed.manchester.ac.uk/subjects/idpm/research/publications/wp/di/

Hewitt, J.J., Wilkenfeld, J., Gurr, T.D. \& Heldt, B. (eds) (2012) Peace and Conflict 2012, Center for International Development and Conflict Management, University of Maryland, College Park, MD http://www.cidcm.umd.edu/pc/executive summary/exec sum 2012.pdf

HLP (2013) A New Global Partnership: Eradicate Poverty And Transform Economies Through Sustainable Development, High-Level Panel of Eminent Persons, United Nations, New York http://www.post2015hlp.org/wp-content/uploads/2013/05/UN$\underline{\text { Report.pdf }}$

ITU (2003) The Geneva Declaration of Principles and Plan of Action, International Telecommunication Union, Geneva http://www.itu.int/wsis/docs/promotional/brochure-dop-poa.pdf

ITU (2013) WSIS Forum 2013 Outcome Document, International Telecommunication Union, Geneva http://www.itu.int/wsis/implementation/2013/forum/inc/doc/outcome/S-POLWSIS.OD FORUM-2013-PDF-E.pdf

ITU (2014a) WSIS+10 High-Level Event, International Telecommunication Union, Geneva http://www.itu.int/wsis/implementation/2014/forum/inc/doc/mpp/WSIS10.hlefinal.briefing presentation.pdf

ITU (2014b) Statistics, International Telecommunication Union, Geneva http://www.itu.int/en/ITU-D/Statistics/Pages/stat/default.aspx 
Lazzarato, M. (2009) Neoliberalism in action, Theory, Culture \& Society, 26(6), 109133

Light, A. (2010) Bridging global divides with tracking and tracing technology, Pervasive Computing, 9(2), 28-36

Mansaray, M. L. (1992) ASYCUDA: a framework for an integrated socio-economic development of ECOWAS countries, in: Social Implications of Computers in Developing Countries, S.C. Bhatnagar \& M. Odedra (eds), Tata McGraw-Hill, New Delhi, 244-260

Marais, M. (2013) An analysis of the factors affecting the sustainability of ICT4D initiatives, paper presented at IDIA2011, Lima, Peru, 26-28 Oct

Maslow, A. (1943) A theory of human motivation, Psychology Review, 50, 370-396

Molony, T. (2012) ICT and mobility, Information Technology for Development, 18(2), $87-90$

Murphy, J.T., Carmody, P. \& Surborg, B. (2014) Industrial transformation or business as usual? Information and communication technologies and Africa's place in the global information economy, Review of African Political Economy, 41(140), 264-283

Nafziger, E.W. (2006) From Seers to Sen: The Meaning of Economic Development, Research Paper 2006/20, UNU WIDER, Helsinki, Finland http://www.wider.unu.edu/publications/working-papers/researchpapers/2006/en GB/rp2006-20/

Narasimhan, R. (1983) The socioeconomic significance of information technology to developing countries, The Information Society, 2(1), 65-79

ODI (2013) What kind of data revolution do we need for post-2015?, Post2015.org, 5 Nov http://post2015.org/2013/11/05/launch-of-a-new-blog-series-what-kind-ofdata-revolution-do-we-need-for-post-2015/

Osei-Bryson, K.-M. \& Vogel, D. (2014) Special issue on cyber-security for development, Information Technology for Development, 20(2), 93-95

Ospina, A.V. \& Heeks, R. (2012) The Future Research Agenda for ICTs, Climate Change and Development, Centre for Development Informatics, University of Manchester, UK

http://www.niccd.org/sites/default/files/ICCD Future Research Agenda Strategy Brief.pdf

Ospina, A.V., Faulkner, D., Dickerson, K. \& Bueti, C. (2014) Resilient Pathways: The Adaptation of the ICT Sector to Climate Change, International Telecommunication 
Union, Geneva http://www.itu.int/en/ITU-

T/climatechange/Documents/Publications/Resilient Pathways-E.PDF

Pant, L. \& Heeks, R. (2011) ICT-Enabled Development of Capacity for Climate Change Adaptation, Centre for Development Informatics, University of Manchester, UK http://www.niccd.org/sites/default/files/PantHeeksClimateChangeAdaptationICTs.p df

Pinker, S. (2011) Violence vanquished, The Wall Street Journal, 24 Sept http://online.wsj.com/news/articles/SB100014240531119041067045765832035894 $\underline{08180}$

Punamaki, R.-L., Wallenius, M., Nygard, C.-H., Saarni, L. \& Rimpela, A. (2007) Use of information and communication technology (ICT) and perceived health in adolescence, Journal of Adolescence, 30(4), 569-585

Ragnedda, M. \& Muschert, G.W. (eds) (2013) The Digital Divide: The Internet and Social Inequality in International Perspective, Routledge, London

Rauniyar, G. \& Kanbur, R. (2009) Inclusive Growth and Inclusive Development, Occasional Paper 8, Asian Development Bank, Bangkok http://www.adb.org/sites/default/files/OP8-inclusive-growth-development.pdf

Rea, J. (2011) Growth comes full circle, The Networker, May-July, 6-7 http://www.bond.org.uk/data/files/The Networker MayJuly 2011 issue 97 high res.pdf

Renken, J. \& Heeks, R. (2013) Conceptualising ICT4D project champions, in: Proceedings of the $6^{\text {th }}$ International Conference on Information and Communication Technologies and Development, Vol. 2, 128-131

Roseveare, N. (2011) Coming full circle, The Networker, May-July, p.3 http://www.bond.org.uk/data/files/The Networker MayJuly 2011 issue 97 high res.pdf

Schop, C. (2009) Maslow's hierarchy of needs, Safety Needs, 22 Jul

SDSN (2013) An Action Agenda for Sustainable Development, Sustainable Development Solutions Networks, Paris http://unsdsn.org/files/2013/11/An-ActionAgenda-for-Sustainable-Development.pdf

Seers, D. (1969) The Meaning of Development, Institute of Development Studies, University of Sussex, Brighton, UK http://www.ids.ac.uk/files/dmfile/themeaningofdevelopment.pdf

Sigman, A. (2011) Does not compute, revisited, in: Too Much, Too Soon?, R. House (ed.), Hawthorn Press, Stroud, UK, 265-288 
Smith, M.L., Elder, L. \& Emdon, H. (2011) Open development: a new theory for ICT4D, Information Technologies and International Development, 7(1), iii-ix

Stiglitz, J.E. (2012) The Price of Inequality, WW Norton, New York, NY

Streeten, P. (1984) Basic needs: some unsettled questions, World Development, 12(9), 973-978

Tarafdar, M., Gupta, A. \& Turel, O. (2013) The dark side of information technology use, Information Systems Journal, 23, 269-275

Theron, P. \& Bologna, S. (eds) (2013) Critical Information Infrastructure Protection and Resilience in the ICT Sector, IGI Global, Hershey, PA

Thompson, M. (2008) ICT and development studies: towards development 2.0, Journal of International Development, 20(6), 821-835

UN (2012) Realizing the Future We Want for All, United Nations, New York, NY http://www.un.org/en/development/desa/policy/untaskteam undf/untt report.pdf

UN (2013) A Renewed Global Partnership for Development, United Nations, New York, NY

http://www.un.org/en/development/desa/policy/untaskteam undf/glob dev rep 2013.pdf

UNCSTD (2011) Implementing WSIS Outcomes: Experience to Date and Prospects for the Future, UN Commission on Science and Technology for Development, Geneva http://www.umic.pt/images/stories/publicacoes5/dtlstict2011d3 en.pdf

UNCTAD (2010) Information Economy Report 2010: ICTs, Enterprise and Poverty Alleviation, UNCTAD, Geneva

UNCTAD (2012) Information Economy Report 2012: The Software Industry and Developing Countries, UNCTAD, Geneva

UNDP (2011) Towards Human Resilience, United Nations Development Programme, New York, NY http://www.undp.org/content/dam/undp/library/Poverty\%20Reduction/Towards S ustainingMDG Web1005.pdf

UNESCO (2013) Information and Knowledge for All: An Expanded Vision and a Renewed Commitment, UNESCO, Paris http://www.itu.int/wsis/review/inc/docs/2013.WSIS10 Final-Statement EN.HD.pdf 
UNGA (2012) The Future We Want, A/RES/66/288, United Nations General Assembly, New York, NY

http://www.un.org/ga/search/view doc.asp?symbol=A/RES/66/288\&Lang=E

UN-HABITAT (2012) Input to Post-2015 UN Development Agenda, UN-HABITAT, Nairobi, Kenya

http://www.un.org/en/development/desa/policy/untaskteam undf/groupb unhabit at suscities.pdf

van Stijn, E., Klievink, B. \& Tan, Y.-H. (2011) Innovative ICT solutions for monitoring and facilitating international Trade, Network Industries Quarterly, 13(3), 26-29

WCED (1987) Our Common Future, Oxford University Press, Oxford, UK

WEF (2013) Global Risks 2013, World Economic Forum, Geneva, Switzerland http://www.weforum.org/reports/global-risks-2013-eighth-edition

Wilkinson, R. \& Pickett, K. (2010) The Spirit Level: Why Equality is Better for Everyone, Penguin Books, London

World Bank (2001) What is Sustainable Development, World Bank, Washington, DC http://www.worldbank.org/depweb/english/sd.html

World Bank (2014) Open Development, World Bank, Washington, DC http://www.worldbank.org/open/

WSIS (2013a) WSIS+10 Visioning Challenge: WSIS Beyond 2015, World Summit on the Information Society, Geneva

http://www.itu.int/wsis/review/inc/docs/WSIS10 Visioning_Challenge-V4.pdf

WSIS (2013b) Identifying Emerging Trends and a Vision Beyond 2015, World Summit on the Information Society, Geneva

http://www.itu.int/wsis/review/inc/docs/emerging.trends.2012-2013.pdf

WSIS (2014a) WSIS+10 Statement on the Implementation of WSIS Outcomes, World Summit on the Information Society, Geneva

http://www.itu.int/wsis/review/mpp/pages/consolidated-texts.html\#statement

WSIS (2014b) WSIS+10 Vision for WSIS Beyond 2015, World Summit on the Information Society, Geneva

http://www.itu.int/wsis/review/mpp/pages/consolidated-texts.html\#vision 


\section{Appendix A: Most Frequently-Appearing Terms in WSIS+10 Documentation}

The table lists the twenty most frequently-appearing terms within the reviewed WSIS+10 documentation, from among those terms used within the current analysis, selected on the basis of their frequency per 10,000 words of text.

\begin{tabular}{|r|l|c|}
\hline Position & Term & $\begin{array}{c}\text { Freq. } \text { per } \\
\mathbf{1 0 , 0 0 0} \text { Words }\end{array}$ \\
\hline 1 & ICT & 98.0 \\
\hline 2 & Information & 76.1 \\
\hline 3 & Government & 50.1 \\
\hline 4 & Access* & 44.2 \\
\hline 5 & Process* & 39.4 \\
\hline 6 & Technol* & 39.2 \\
\hline 7 & Stakehold* & 37.3 \\
\hline 8 & Internet & 36.5 \\
\hline 9 & Communicat* & 33.8 \\
\hline 10 & Policy/Policies & 25.8 \\
\hline 11 & Knowledge & 24.9 \\
\hline 12 & Particip* & 23.9 \\
\hline 13 & Digital & 22.8 \\
\hline 14 & Education & 22.2 \\
\hline 15 & Implementation & 19.3 \\
\hline 16 & Public & 19.2 \\
\hline 17 & Innovati* & 18.5 \\
\hline 18 & Data & 17.8 \\
\hline 19 & Environment* & 17.7 \\
\hline 20 & Open & 17.0 \\
\hline
\end{tabular}




\section{Appendix B: Composition of Key Development Issues}

The table shows the component words/terms that were aggregated to form the 25 key development issues reported in the main text. Coverage is not comprehensive of every possible term and issue but as explained in Heeks (2014a), these were developed on the basis of both word counts and broader literature review.

\begin{tabular}{|c|c|}
\hline \multicolumn{2}{|l|}{ DEVELOPMENT GOALS } \\
\hline \multirow[t]{12}{*}{ MDGs 1-6 } & Poverty \\
\hline & Hunger \\
\hline & Education \\
\hline & Child \\
\hline & Women \\
\hline & Gender \\
\hline & Girl \\
\hline & Maternal \\
\hline & Health \\
\hline & Mortality \\
\hline & HIV/AIDS \\
\hline & Malaria \\
\hline \multirow[t]{5}{*}{ Growth and Jobs } & Growth \\
\hline & Enterprise \\
\hline & Entrepreneur \\
\hline & Employ* \\
\hline & Job \\
\hline \multirow[t]{2}{*}{ Rural/Agricultural Development } & Agric* \\
\hline & Rural \\
\hline \multirow[t]{2}{*}{ Urban Development } & Urban \\
\hline & City/Cities [whole words] \\
\hline \multirow[t]{3}{*}{ Institutional Development } & Governance \\
\hline & Institution \\
\hline & Politic* \\
\hline \multirow[t]{3}{*}{ Rights and Justice } & Justice \\
\hline & Rights \\
\hline & Social Justice \\
\hline \multirow[t]{3}{*}{ Livelihoods } & Livelihood \\
\hline & Capabilit* \\
\hline & Vulnerab* \\
\hline Migration & Migra* \\
\hline Manufacturing & Manufacturing \\
\hline Services & Services \\
\hline Infrastructure & Infrastructur* \\
\hline \multirow[t]{4}{*}{ Insecurity } & Conflict \\
\hline & Humanitarian \\
\hline & Violen* \\
\hline & War(s) [whole words] \\
\hline
\end{tabular}




\begin{tabular}{|c|c|}
\hline & Peace \\
\hline & Security \\
\hline \multirow[t]{6}{*}{ MDG 8} & Trade \\
\hline & Least developed \\
\hline & Landlocked \\
\hline & Small island \\
\hline & Debt \\
\hline & Drug \\
\hline \multirow[t]{3}{*}{ Wellbeing } & Psychol* \\
\hline & Happy/Happiness \\
\hline & Well-being/Wellbeing \\
\hline \multirow[t]{6}{*}{ Environment and Sustainability } & Environment* \\
\hline & Sustainab* \\
\hline & Climate Change \\
\hline & Energy \\
\hline & Disaster \\
\hline & Waste \\
\hline \multirow[t]{4}{*}{ Open Development } & Open [not Copenhagen] \\
\hline & Transparen* \\
\hline & Accountab* \\
\hline & Corrup* \\
\hline \multirow[t]{6}{*}{ Inclusive Development } & Inclusi* \\
\hline & (In)equalit* \\
\hline & Exclusion/Excluded \\
\hline & Diversity [whole word] \\
\hline & Grassroot \\
\hline & Disab* \\
\hline \multicolumn{2}{|l|}{ DEVELOPMENT MECHANISMS } \\
\hline \multirow[t]{5}{*}{ Informatics } & ICT [specific term] \\
\hline & Information \\
\hline & Digital \\
\hline & Data \\
\hline & Mobile \\
\hline \multirow[t]{3}{*}{ Technovation } & Scien* \\
\hline & Technol* \\
\hline & Innovati* \\
\hline \multirow[t]{3}{*}{ Traditional Development Finance } & Aid [whole word] \\
\hline & ODA \\
\hline & Donor \\
\hline \multirow[t]{3}{*}{ New Development Finance } & Tax \\
\hline & Remittance \\
\hline & Philanthrop* \\
\hline New Stakeholders & Business \\
\hline
\end{tabular}




\begin{tabular}{|l|l|}
\hline & Communit* \\
\hline & Stakehold* \\
\hline & Cooperation \\
\hline & Partnership \\
\hline & Collab* \\
\hline Development Projects & Particip* \\
\hline & Implementation \\
\hline & Delivery \\
\hline & Management \\
\hline & Process* \\
\hline Development Strategy & Evaluat* \\
\hline & Monitor \\
\hline & Strateg* \\
\hline & Law \\
\hline DEVELOPMENT PERSPECTIVES & Policy/Policies \\
\hline Complex Adaptive Systems & \\
\hline & Resilien* \\
\hline & Complex/Complic* \\
\hline & Agile \\
\hline & Uncertain \\
\hline & Volatil* \\
\hline & System* \\
\hline & Connec* \\
\hline & Adapt* \\
\hline & Shock(s) [whole words] \\
\hline & Risk \\
\hline & \\
\hline & \\
\hline &
\end{tabular}


Appendix C: Differences Between Post-2015 and ICT4D/WSIS+10 Text Two tables are shown here. The first - Table C1 - calculates comparative frequencies between WSIS+10 and post-2015 documentation for a series of individual terms. The lower the number below zero, the more the term is underrepresented in WSIS documentation compared to post-2015 documentation. The higher the number above zero, the more it is over-represented. Some of these terms are stand-alone, and some are used as the basis (see Appendix B) for aggregated issues, which are shown in the second table; Table C2.

In both tables, as in Figure 1, the statistic shown is created in the following manner:

- ' $A$ ' represents the absolute difference in frequency of occurrences per 10,000 words, subtracting the PTDA figure from the WSIS figure.

- ' $R$ ' represents the relative difference for these statistics: dividing the absolute difference by the PTDA figure.

- The standard deviation of $A$ and $R$ is calculated for all data shown (a somewhat rough-and-ready calculation given the data is unlikely to be normally distributed): SA and SR.

- The measure shown is calculated as the average deviation of each entry: ((A/SA) $+(\mathrm{R} / \mathrm{SR})) / 2$.

\begin{tabular}{|l|c|}
\hline Individual Development Issue & $\begin{array}{c}\text { Difference of } \\
\text { ICT4D (WSIS+10) } \\
\text { from PTDA }\end{array}$ \\
\hline Sustainab* & -4.2 \\
\hline Poverty & -1.6 \\
\hline Partnership & -1.4 \\
\hline Finan* & -1.4 \\
\hline System* & -1.2 \\
\hline Food & -1.1 \\
\hline Energy & -1.0 \\
\hline Economic & -1.0 \\
\hline Resource & -1.0 \\
\hline Social & -0.9 \\
\hline Environment* & -0.9 \\
\hline Accountab* & -0.9 \\
\hline Water & -0.9 \\
\hline Growth & -0.8 \\
\hline Trade & -0.7 \\
\hline Income & -0.7 \\
\hline Equalit* [inc. inequalit*] & -0.7 \\
\hline Institution & -0.6 \\
\hline Job & -0.6 \\
\hline Violen* & -0.6 \\
\hline Transform* & -0.6 \\
\hline Peace & -0.6 \\
\hline Aid [whole word] & -0.6 \\
\hline
\end{tabular}




\begin{tabular}{|c|c|}
\hline Individual Development Issue & $\begin{array}{c}\text { Difference of } \\
\text { ICT4D (WSIS+10) } \\
\text { from PTDA }\end{array}$ \\
\hline Migra* & -0.6 \\
\hline $\begin{array}{l}\text { Rights [whole word - not } \\
\text { copyright] }\end{array}$ & -0.5 \\
\hline Nutrition & -0.5 \\
\hline Land [whole word] & -0.5 \\
\hline Debt & -0.5 \\
\hline Law [whole word] & -0.5 \\
\hline Sanitation & -0.5 \\
\hline Child & -0.5 \\
\hline Climate Change & -0.5 \\
\hline State(s) [whole words] & -0.5 \\
\hline Urban & -0.5 \\
\hline Livelihood & -0.5 \\
\hline Conflict & -0.4 \\
\hline Health & -0.4 \\
\hline Vulnerab* & -0.4 \\
\hline Poor & -0.4 \\
\hline Politic* & -0.4 \\
\hline Risk & -0.4 \\
\hline Population & -0.4 \\
\hline Resilien* & -0.4 \\
\hline Justice & -0.4 \\
\hline Green & -0.4 \\
\hline Social Protection & -0.4 \\
\hline Food Security & -0.4 \\
\hline Hunger & -0.4 \\
\hline Small island & -0.4 \\
\hline Bank* & -0.4 \\
\hline ODA & -0.4 \\
\hline Carbon & -0.3 \\
\hline City/Cities [whole words] & -0.3 \\
\hline Market & -0.3 \\
\hline Transparen* & -0.3 \\
\hline Donor & -0.3 \\
\hline Monitor & -0.3 \\
\hline Tax & -0.3 \\
\hline Disaster & -0.3 \\
\hline Least developed & -0.3 \\
\hline Mortality & -0.3 \\
\hline Cooperation & -0.3 \\
\hline Corrup* & -0.3 \\
\hline Crisis/Crises & -0.3 \\
\hline
\end{tabular}




\begin{tabular}{|c|c|}
\hline Individual Development Issue & $\begin{array}{c}\text { Difference of } \\
\text { ICT4D (WSIS+10) } \\
\text { from PTDA }\end{array}$ \\
\hline Philanthrop* & -0.3 \\
\hline Fragil* & -0.3 \\
\hline Shock(s) [whole words] & -0.3 \\
\hline Landlocked & -0.3 \\
\hline HIV/AIDS & -0.3 \\
\hline Renewable & -0.3 \\
\hline Commodit* & -0.3 \\
\hline Investment & -0.3 \\
\hline Volatil* & -0.3 \\
\hline Maternal & -0.3 \\
\hline Malaria & -0.3 \\
\hline Remittance & -0.2 \\
\hline Employ* & -0.2 \\
\hline Hope & -0.2 \\
\hline Drug & -0.2 \\
\hline Well-being/Wellbeing & -0.2 \\
\hline Housing & -0.2 \\
\hline Uncertain & -0.2 \\
\hline Impact & -0.2 \\
\hline Girl & -0.2 \\
\hline Faith & -0.2 \\
\hline Energy Security & -0.2 \\
\hline Productivity & -0.2 \\
\hline Agric* & -0.2 \\
\hline Emotion & -0.2 \\
\hline Exclusion/Excluded & -0.2 \\
\hline Social Justice & -0.2 \\
\hline Leaders* & -0.2 \\
\hline Minorit* & -0.2 \\
\hline Money & -0.2 \\
\hline Women & -0.2 \\
\hline Female & -0.2 \\
\hline Oil [whole word] & -0.2 \\
\hline Waste & -0.2 \\
\hline Shelter & -0.1 \\
\hline Management & -0.1 \\
\hline Gender & -0.1 \\
\hline Business & -0.1 \\
\hline Humanitarian & -0.1 \\
\hline Geograph* & -0.1 \\
\hline Terror* & -0.1 \\
\hline Inclusi* & -0.1 \\
\hline
\end{tabular}




\begin{tabular}{|c|c|}
\hline Individual Development Issue & $\begin{array}{c}\text { Difference of } \\
\text { ICT4D (WSIS+10) } \\
\text { from PTDA } \\
\end{array}$ \\
\hline Complex/Complic* & -0.1 \\
\hline Adapt* & 0.0 \\
\hline War(s) [whole words] & 0.0 \\
\hline Local & 0.0 \\
\hline Religi* & 0.0 \\
\hline Implementation & 0.0 \\
\hline Woman & 0.0 \\
\hline Capabilit* & 0.0 \\
\hline Rural & 0.0 \\
\hline Capacit* & 0.1 \\
\hline Delivery & 0.1 \\
\hline Policy/Policies & 0.1 \\
\hline Public & 0.1 \\
\hline Communit* & 0.1 \\
\hline Security & 0.1 \\
\hline Grassroot & 0.2 \\
\hline Militar* & 0.2 \\
\hline Youth & 0.2 \\
\hline Diversity [whole word] & 0.2 \\
\hline Governance & 0.2 \\
\hline Manufactur* & 0.2 \\
\hline Education & 0.2 \\
\hline Enterprise & 0.2 \\
\hline Emerging & 0.3 \\
\hline Scien* & 0.3 \\
\hline Free* & 0.3 \\
\hline Skill & 0.3 \\
\hline Private & 0.3 \\
\hline Collab* & 0.3 \\
\hline Disab* & 0.4 \\
\hline Strateg* & 0.4 \\
\hline Civil Society & 0.4 \\
\hline Services & 0.5 \\
\hline Learning & 0.5 \\
\hline Access* & 0.6 \\
\hline Open [not open consultation] & 0.7 \\
\hline Entrepreneur & 0.7 \\
\hline Evaluat* & 0.7 \\
\hline Citizen & 0.7 \\
\hline Particip* & 0.7 \\
\hline Regulat* & 0.7 \\
\hline Innovati* & 0.7 \\
\hline
\end{tabular}




\begin{tabular}{|l|c|}
\hline Individual Development Issue & $\begin{array}{c}\text { Difference of } \\
\text { ICT4D (WSIS+10) } \\
\text { from PTDA }\end{array}$ \\
\hline Infrastructur* & 0.9 \\
\hline Moral [not morale] & 0.9 \\
\hline Culture [whole word] & 0.9 \\
\hline Technol* & 1.1 \\
\hline Non-gov/NGO & 1.2 \\
\hline Competit* & 1.2 \\
\hline Process* & 1.5 \\
\hline Government & 1.7 \\
\hline Stakehold* & 2.0 \\
\hline Universit* & 2.4 \\
\hline Ethic* & 5.6 \\
\hline
\end{tabular}

Table C1: ICT4D Gap Measure for Individual Terms

Note that Table C1 excludes terms related to informatics which are all inherently over-represented in WSIS documentation compared to PTDA documentation. It also excludes terms not present in the PTDA documentation since they would return null values for percentage change (these are: commerce, weapon, nuclear, psychol*, happy/happiness, corporate social, agile, chao* and privacy). 


\begin{tabular}{|l|c|}
\hline $\begin{array}{l}\text { Aggregated Development } \\
\text { Issue }\end{array}$ & $\begin{array}{c}\text { Difference of } \\
\text { ICT4D (WSIS+10) } \\
\text { from PTDA }\end{array}$ \\
\hline $\begin{array}{l}\text { Environment and } \\
\text { Sustainability }\end{array}$ & -1.4 \\
\hline MDGs 1-6 & -0.7 \\
\hline MDG 8 & -0.5 \\
\hline Traditional Development & -0.4 \\
\hline Finance & -0.4 \\
\hline Complex Adaptive Systems & -0.3 \\
\hline Growth and Jobs & -0.3 \\
\hline Insecurity & -0.3 \\
\hline Urban Development & -0.3 \\
\hline Migra* & -0.3 \\
\hline Livelihoods & -0.3 \\
\hline New Development Finance & -0.3 \\
\hline Rights and Justice & -0.2 \\
\hline Institutional Development & -0.2 \\
\hline Open Development & -0.2 \\
\hline Wellbeing & -0.1 \\
\hline Inclusive Development & -0.1 \\
\hline Rural/Agricultural & 0.0 \\
\hline Development & 0.1 \\
\hline Development Strategy & 0.2 \\
\hline New Stakeholders & 0.3 \\
\hline Services & 0.3 \\
\hline Manufactur* & 0.6 \\
\hline Development Projects & 0.6 \\
\hline Technovation & 4.3 \\
\hline Infrastructur* & \\
\hline Informatics & \\
\hline & \\
\hline
\end{tabular}

Table C2: ICT4D Gap Measure for Aggregated Issues 


\section{Appendix D: ICT4D Value Chain Emphases Within WSIS+10 Documentation}

The table below shows the frequency of appearance in WSIS+10 documentation of terms associated with the four stages of the ICT4D value chain (see Figures 7 and 8).

\begin{tabular}{|c|c|c|}
\hline $\begin{array}{l}\text { Aggregate Term/ } \\
\text { Value Chain Stage }\end{array}$ & Constituent Terms & $\begin{array}{c}\text { Freq. per } \\
10,000 \text { Words }\end{array}$ \\
\hline \multirow[t]{4}{*}{ Readiness } & & 20.6 \\
\hline & Readiness & 0.3 \\
\hline & Infrastructur* & 14.9 \\
\hline & Divide(s) [whole words] & 5.4 \\
\hline \multirow[t]{4}{*}{ Availability } & & 28.3 \\
\hline & Availability & 2.8 \\
\hline & Design & 6.1 \\
\hline & Implementation & 19.3 \\
\hline \multirow[t]{4}{*}{ Uptake } & & 8.4 \\
\hline & Uptake & 0.5 \\
\hline & Adopt* & 5.5 \\
\hline & Scal* & 2.5 \\
\hline \multirow[t]{4}{*}{ Impact } & & 17.0 \\
\hline & Impact & 7.3 \\
\hline & Output & 0.3 \\
\hline & Benefit & 9.4 \\
\hline
\end{tabular}

